This is the post-print version of a published work. Please, cite as:

RAMON-MUÑOZ, Ramon and RAMON-MUÑOZ, Josep-Maria (2017):

"Sibship size and the biological standard of living in industrial Catalonia, c.1860-c.1920: a case study", The History of the Family, vol. 22, nos. 23, pp. 333-363. DOI: https://doi.org/10.1080/1081602X.2016.1224727

\title{
Sibship size and the biological standard of living in industrial Catalonia, c.1860-c.1920: a case study
}

Ramon Ramon-Muñoz ${ }^{\mathrm{a}}$ and Josep-Maria Ramon-Muñoz ${ }^{\mathrm{b}}$

\begin{abstract}
By using military records and population censuses this article investigates the relationship between sibship size and the biological living standards of young males, as measured by height. Focusing on a medium-sized industrial town in Catalonia the analysis shows that the impact of sibship size on child outcomes, as hypothesised by the resource dilution explanation, was rather weak during the years of the first fertility transition. Sibship size affected the height of young males only in certain socioeconomic groups and in specific periods of time, and not always in the expected direction. The article also explores the potential role of confounding factors in the link between sibship size and height, as well as the complexity of this relationship.
\end{abstract}

KEYWORDS: Height; sibship size; resource dilution; fertility transition; Southern Europe

\footnotetext{
${ }^{a}$ Department of Economic History, Institutions, Policy and World Economy, Faculty of Economics and Business, University of Barcelona, Barcelona, Spain; b Department of Applied Economics, Faculty of Economics and Business, University of Murcia, Murcia, Spain
} 


\section{Introduction}

Does sibship size influence child outcomes? The resource dilution hypothesis suggests that it does (Blake, 1981, 1989). Consistent with the notion of quality-quantity trade-off in classical family economics and modern unified growth theory, the resource dilution hypothesis predicts a negative association between sibship size and various indicators of child quality, including, among others, educational attainment, social mobility, early-life mortality, and health and nutritional status. ${ }^{1}$ In a nutshell, it argues that the more children a couple has (and the larger the family is), the lower the quality of the children will be. This negative relationship is considered to result from the fact that the more children a couple has, the more the parental resources will be divided and diluted. Parental resources are therefore assumed to be finite, although proponents of the resource dilution hypothesis also state that some of these resources are more finite than others (e.g. Downey, 1995, 2001).

The literature in this field is enormous and impossible to summarise. A particularly large body of work has considered the influence of sibship size on children's educational attainment, due likely to the importance of human capital for both economic growth and human development. In addition, most of the studies have tended to rely on modern quantitative information rather than on empirical evidence pre-dating World War II, possibly because of difficulties in accessing the historical data. Interestingly, all this body of research has produced some puzzling results: although much of this literature has lent support to the resource dilution hypothesis, there are also numerous studies suggesting that the negative association between sibship size and child outcomes is not always as consistent as might be expected, and that sometimes the association may even be positive (e.g. Angrist, Lavy, \& Schlosser, 2010; Black, Devereux, \& Salvanes, 2005; Desai, 1995; Eloundou-Enyegue \& Williams, 2006; Guo \& Van Wey, 1999; Kessler, 1991; Lee, 2008; Lu \& Treiman, 2008; Maralani, 2008; Qian, 2009; Razzaque, Streatfield, \& Evans, 2007; Sudha, 1997; Yu \& Su, 2006; see also the reviews by Buchmann \& Hannum, 2001; Steelman, Powell, Werum, \& Carter, 2002).

Recently, this literature has received a new boost. In many cases 
encouraged by unified growth theory, scholars have begun to investigate historically the hypothesised child quantity- quality trade-off and, by extension, the resource dilution hypothesis. As a result, there is a new and growing body of historical evidence at the household level on the effect of sibship size, family size or fertility decline on several indicators of offspring outcomes, including school attendance (Becker, Cinnirella, \& Woessmann, 2010; Bleakley \& Lange, 2009; Fernihough, 2011; Parman, 2015), literacy status and professional skills (Klemp \& Weisdorf, 2012), social mobility (Bras, Kok, \& Mandemakers, 2010; Van Bavel, 2006; Van Bavel, Moreels, Van de Putte, \& Matthijs, 2011), health and nutrition (Bailey, Hatton, \& Inwood, 2016; Hatton, 2015; Hatton \& Martin, 2010a, 2010b; Öberg, 2015) and mortality (Kippen \& Walters, 2012). ${ }^{2}$

The new historical literature mostly confirms the negative association between child numbers and child achievements. However, some of the abovementioned studies have pointed out that this association may differ over time and across social groups. A clear example of the former is provided by Van Bavel (2006). After investigating social mobility in the Belgian city of Leuven during the nineteenth century, he concluded that "children from smaller families were more likely to climb up to, or stay in, the upper classes than children from bigger families', adding that 'if the relation between family size and intergenerational mobility has a major explanatory value for the fertility transition, the kind of effects found here should not be found before the demographic transition' (Van Bavel, 2006, p. 568, emphasis in original).

Through the analysis of more than one million marriage certificates from five Dutch provinces for the period 1812-1922, Bras et al. (2010) also concluded that the negative impact of sibship size increased over time. In addition, they found no detrimental impact of large sibship size on social status at marriage in the case of children from farmers' and farm labourers' households. The authors argue that children in these families became productive earlier, with older children subsidising the younger ones. In addition, Bras et al. (2010) found that the effect of sibship size on status at marriage was positive in areas with high proportions of co-residing kin and was not significantly less 
disadvantageous in largely Catholic communities, since extended kin groups and social institutions outside the family tended to provide a buffer for diluted resources in large families.

The changing impact of sibship size over time and across social groups has also been noted by other scholars. Using household data for England and Wales for the first third of the twentieth century, Hatton and Martin (2010a, 2010b) and Hatton (2015) showed that family size (and also sibship size) negatively affected the height of children, although their analysis also suggested that this negative effect may vary over time. For example, Hatton (2015) concluded that the negative impact of sibship size on height was larger in the so-called Boyd Orr survey, formed by 1343 households with school-aged children in England and Scotland during the years 1937-1939, than it was in a sample of men born in the 1890s and enlisted in the armed forces during World War I. Interestingly, Hatton and Martin (2010a, 2010b) also argued that the inverse association between sibship size and height resulted not only from the dilution of income but also from overcrowding and the degree of cleanliness or hygiene in the household, which, in turn, worsened the disease environment.

According to these authors, the reduction in family size would also have been an important contributor to the height gains that took place in the United Kingdom prior to the outbreak of World War II. In Sweden, Öberg (2015) used information from universal conscript inspections linked to the Scanian Economic Demographic Database (SEDD) to analyse the link between sibship size and height among men born between 1797 and 1950 in five rural parishes in southern Sweden. Although he found a negative association between sibship size and height, his results also showed that this association was only steadily statistically significant in the male cohorts of 1891-1920, namely around the time of the fertility decline, whereas its strength gradually weakened over time. Furthermore, the link between sibship size and height was, overall, strongly influenced by observable differences between the families, suggesting a rather complex relationship between these two variables. Van Bavel et al. (2011) also reported a negative impact of sibship size, this time for intergenerational mobility in the Belgian city of Antwerp between 
1846 and 1920. It should be noted, however, that these latter scholars also found that the importance of sibship size was greater for children born in the middle class, and that sibship size limitation was only effective as a defensive strategy.

That socioeconomic status has to be considered seems also apparent when the literature on fertility transition is analysed. According to this literature, the reproductive behaviour of individuals and social groups tends to differ depending on their socioeconomic status (e.g. Boberg-Fazlic, Sharp, \& Weisdorf, 2011; Clark \& Hamilton, 2006; Dribe \& Scalone, 2014; LiviBacci, 1986; Skirbekk, 2008). In pre-industrial Western Europe, most studies show that the size of upper-class families was generally higher than that of lower-class families. During the demographic transition, this pattern would have reversed, and higher socioeconomic status would have ceased to be associated with higher fertility rates, at least in Western Europe. Elites would have been the first to reduce their number of children, although in the course of the fertility transition this reduction would have spread to other social classes as well. The end result would have been a general decline in fertility rates as the twentieth century progressed.

This account of the fertility transition is clear and broadly accepted. Yet, it has recently been challenged. For example, Dribe and Scalone (2014) analysed the status-fertility relationship in Sweden between 1860 and 1960 and found that fertility differences across social groups remained over the period under consideration. They showed that by the early stages of the fertility transition the upper and middle classes already had substantially lower fertility rates than did lower skilled workers, and that these differences among socioeconomic groups remained until the 1960s, which would stress the importance of considering the socioeconomic status of families in testing the resource dilution hypothesis.

Whereas historical evidence points to differences in the relationship between sibship size and child outcomes at different stages of the fertility decline as well as across different socioeconomic groups, this evidence is still relatively scarce and is largely limited to north-western European countries. This article aims to go some way to filling this gap. By using military records 
and population censuses it investigates the relationship between sibship size, as measured by the number of siblings alive, and nutritional status, as measured by the recruit's height. Focusing on a medium-sized industrial town in Catalonia during the period of rapid fertility decline (i.e. 1860-1920) the analysis suggests that the link between sibship size and height was rather weak. The article also explores the potential role of confounding factors in the link between sibship size and height, as well as the complexity of this relationship. More specifically, the results show that sibship size affected the height of young males only in certain socioeconomic groups and in specific periods of time, and that in most cases its impact was statistically non-significant.

The article is organised as follows. Section 2 offers a general overview of the economy, demography, and living standards of Igualada during the nineteenth century and the early twentieth century. Section 3 describes the main characteristics and the main potential shortcomings of the dataset used for this article. Section 4 presents an analysis of the relationship between sibship size and height by differentiating by periods and socioeconomic groups. Section 5 tests this potential relationship through multivariate regressions. The paper ends with a series of conclusions in Section 6.

\section{Industrialisation, demographic transition and biological living standards}

For a region on the European periphery, Catalonia underwent industrialisation unusually early (Nadal, 1975; Pollard, 1981). At the forefront of the Catalan industrialisation there were cities like Igualada. Located some 60 kilometres west of Barcelona (Figure $1)$, by the 1760s it already was one of the largest woollen-clothmanufacturing cities in Catalonia (Torras, 1991). In the course of the following decades, it shifted successfully from proto-industrial wool manufacture to factory-based cotton production. And by the 1840s, Igualada and its surrounding area had become Catalonia's largest cotton centre, in terms of both numbers of workers and numbers of spindles (Torras i Ribé, 1979).

Paralleling the expansion of the cotton industry, Igualada experienced a period of rapid demographic increase until the mid- 
1850 s. In the peak census year of 1857 it had 14,000 inhabitants, as against 4925 in 1787 . This represents a population increase of $1.4 \%$ per year, a growth rate higher than the Catalan average (Nicolau, 1990). Although the difference between the number of baptisms and the number of burials was always positive, immigration accounted for a large share of Igualada's population growth during the first half of the nineteenth century. It can be estimated that by around 1850, between one-third and two-fifths of Igualada's inhabitants had been born outside the town, most of them in neighbouring towns and counties (Camps, 1995; Marfany, 2001). Not surprisingly, rapid population growth led to an explosion in population density, which reached the figure of almost 1700 inhabitants per square kilometre in the mid-1850s.

As in other areas of western Europe, factory-based industrialisation and rapid urban growth had their costs in terms of biological living standards (e.g. Craig, 2016; Floud, Fogel, Harris, \& Hong, 2011; Martínez-Carrión \& Pérez-Castejón, 1998). The height of Igualada's young males born between the 1830s and the 1850 s decreased by more than two centimetres, with a further decline in the physical height of males taking place in the cohorts born during the early 1860 s, a period of industrial recession and high unemployment (Ramon- Muñoz \& Ramon-Muñoz, 2015, 2016, in press; which situates this deterioration of biological living standards in the western European context). After this period, health and nutritional conditions in the town began to improve, although the industrial recession had not yet ended. In fact, industrial growth only resumed in Igualada in the last decade of the nineteenth century, and continued to flourish during the first third of the twentieth, mainly due to the arrival of the railways in the early 1890 s, the use of electricity power since the early 1900s, and the connection to the hydroelectricity grid in the early 1910s (Pascual, 1991; R. Ramon-Muñoz, 2006; Térmens, 1983).

[Figure 1 about here]

The improvement in biological living standards in a context of sluggish industrial and economic growth is intriguing. Among the potential factors that might explain it, one appears obvious in the light of the resource dilution hypothesis, namely demographic transition and, more precisely, fertility decline. Indeed, after more 
than a century and a half of vigorous increase, population growth in Igualada decelerated and, in fact, became negative during the second half of the nineteenth century $(-0.7 \%$ per year between 1857 and 1900). This drop was coincident with the town's industrial recession during the second half of the nineteenth century, although it might also be considered a new stage of its demographic transition process.

The demographic transition in Igualada warrants some general comments. First, this town deviated from the classical model of demographic transition. Indeed, the period in which both birth and death rates began to decline was rather similar, namely the years around 1830. This pattern of simultaneity in decreasing mortality and natality seems to have also been present in some other areas of Catalonia (Nadal, 1961; Nadal \& Sáez, 1972), in which respect Igualada and other Catalan towns might have been mirroring the pattern in France, where fertility rates began to decline in the second half of the eighteenth century - well before the same occurred in most other western European countries - and paralleled the fall of death rates (e.g. Coale, 1986; Cummins, 2013; Vallin, 2006; Wrigley, 1985a, 1985b). Second, while in Igualada crude birth rates, as well as other indicators such as the number of baptisms per marriage, began to decline in the 1830s, they fell rapidly between the last third of the nineteenth century and the early decades of the twentieth. For example, the average number of baptisms per marriage decreased from almost 5 in the period 1855-1864 to around 2.5 in 1915-1924 (Figure 2). During the last third of the nineteenth century, the reduction in marital fertility rates also accelerated rapidly in Catalonia (Benavente, 1989, 1990; Nadal, 1986; Nicolau, 1990, 1991), following the pattern in western Europe (e.g. Coale, 1986; Galor, 2012; and Guinnane, Okun, \& Trussell, 1994 for a discussion). As a result, by 1930 the average number of children per woman was 2.26 in Catalonia, namely the same figure as in France and one that was lower in comparison with Spain (3.63) (Cabré, 1999, p. 66). Of course, these aggregate figures mask remarkable regional and provincial differences (e.g. for France: Murphy, 2015; Weir, 1984; for Spain: Gil Alonso, 2007; Leasure, 1963; Livi-Bacci, 1968a, 1968b; Nicolau, 1991). 
[Figure 2 about here]

Did the decline in family size influence biological living standards? Figure 2 suggests that in Igualada it did. The rapid decline in fertility rates after the early 1860 s paralleled the recovery and intense growth in the average height of young males born after the period 1854-1865. In addition, and during certain periods, short-term increases (declines) in the average number of baptisms per marriage matched short-term declines (increases) in the average height of young males.

What might be the case for Igualada may not apply to other localities. Nonetheless, there are other examples of an apparent association between height and fertility. During the last quarter of the nineteenth century, height increased by between 2 and 6 centimetres in southern and eastern regions of Spain, i.e. Andalusia, Murcia and Valencia (Cámara, 2007; Martínez- Carrión \& Moreno-Lázaro, 2007; Martínez-Carrión, Pérez de Perceval, \& Martínez-Soto, 2014; Puche, 2011). Over the same period, marital fertility rates also fell substantially in these regions: between 1860 and 1900 the estimated number of legitimate live births per 1000 married women, aged 16-50, declined from 260.6 to 229.2 in Andalusia, from 264.0 to 235.2 in Murcia and from 251.1 to 220.8 in Valencia (Livi-Bacci, 1968b, pp. 228-229).

\section{[Table 1 about here]}

However, these are only rough impressions, based on aggregate data and a quick look at the general quantitative information. Only by making use of household data can sibship size be properly known, and only by applying a more robust quantitative analysis can the relationship between sibship size and height be assessed. To this end, a dataset for the town of Igualada has been constructed. The next section describes the main features of this dataset, as well as its potential shortcomings.

\section{The dataset: sources, data and potential shortcomings}

The dataset that underpins this study relies heavily on data collected from military records and population censuses. It was constructed using three benchmarks covering the period from the 
mid-nineteenth to the early twentieth century. More specifically, it contains information on height, sibship size and a number of other variables for the cohorts of males born in the periods 1845-1850, 1875-1880 and 1905-1910. In total, complete information was obtained for almost 1000 individuals and around 900 different households (Table 1).

This dataset was constructed by following two steps. First, we collected height data from the local lists of recruitment for military service, known as the Acts of Classification and Declaration of Soldiers (Actas de Clasificación y declaración de soldados). It is worth noting that apart from height, these recruitment lists give the forename and the two surnames of each conscript and the forenames of his parents. ${ }^{3}$ The draftee's year and place of birth as well as his occupation and literacy level are also provided in some cases. Finally, the Acts of Classification indicate whether a young man listed for recruitment was considered fit to serve and the grounds on which he was excluded, where this was the case. The conscripts' allegations in response to these decisions are also included in the source.

Importantly, the collected height data from the Acts of Classification and Declaration of Soldiers are not affected by truncation, which is one of the potential shortcomings of military samples (e.g. Komlos, 2004); neither do they seem to be affected by selection bias, which is another possible drawback of historical height data. In Spain the Recruitment Act of 1837, and subsequent Acts, made military service obligatory for all men (e.g. Cámara, 2006). Thus, from the late 1830s onwards an increasing number of young Spanish men began to be called up for military service when they reached the enlistment age, regardless of their social, economic and physical condition. Progressively drafted under universal and compulsory conscription, the recruits were also summoned for measurement and inspection, and then classified. With the obvious exception of those absent during the measurement and inspection process, the height of all draftees was recorded by the military authorities; this was the case regardless of whether the conscript was considered fit to serve. By examining the cohorts of males born in the periods 1845-1850 (recruitment period 1865-1870), 1875-1880 (1894-1899) and 1905-1910 
(1926-1931), we collected height data on 1288 individuals who were around 20 years old at the time of measurement. The difference between this latter figure (1288 individuals with height data) and the figure for the total number of conscripts shown in Table 1 (1708 individuals) is explained by the fact that some of the potential conscripts were absent on the day they were summoned for measurement by the local authorities, whether due to migration, temporary absence or desertion. The most extreme case can be seen in the mid-nineteenth century: of the males born in the period 1845-1850 and recruited in 1865-1870, only half appear with height data in local military service recruitment lists, where individuals with no height data are classified as absent draftees. The high percentage of absences can be attributed primarily to the industrial crisis that hit Igualada after the 1850s, which brought dwindling employment opportunities and worsening living stands, making emigration an attractive proposition. Indeed, in the 30 years after the peak census year of 1857, the city's population fell by $27 \%$, from 14,000 to 10,200 inhabitants (Ramon- Muñoz \& Ramon-Muñoz, 2015, 2016, in press).

The second step in constructing our dataset was to link the collected data on conscripts and heights to the demographic information available in the local population censuses, the socalled Padrón Municipal de Habitantes. Of course, local population censuses give the forenames and the two surnames of all household members, their place of residence and the household's address. In general, these censuses also include the place and date of birth of householders, their marital status and specific position in the household (e.g. head of household, spouse, daughter, domestic servant and so on), whether they were able to read and write, and the occupation of the male household members. ${ }^{4}$

By linking military and demographic records, the aim was to obtain information on the structure of the households in which the conscripts had grown up. The process was costly but relatively simple and accurate. First, we transcribed all of the information on names provided by the Acts of Classification and Declaration of Soldiers and the local population censuses for the years under consideration. Second, we manually linked these two datasets through the conscripts' full name, i.e. the forename, father's 
surname and mother's surname. Third, we carefully checked that the forenames of the conscripts' parents included in the military records coincided with the information provided by the demographic records. About $80 \%$ of the conscripts with height data were found when searching the local population censuses, with a minimum of $68 \%$ in the mid decades of the nineteenth century for the reasons stated above. ${ }^{5} \mathrm{By}$ using this source, we eventually reconstructed the families of 988 conscripts for the census years of 1860, 1890 and 1920. In particular, we collected information on the number of children alive in the family, the birth order of children, the father's literacy and the father's occupation at the time of the census. All this information had been gathered when the focal conscript was aged 10 years. For example, for a conscript born in the period 1845-1850 we used the population census of 1860 to obtain information on the structure of the household when he was 10 years old.

[Figure 3 and Table 2 about here]

Figure 3 and Table 2 show the basic descriptive statistics for our dataset. Note that the total number of observations is now 987 instead of 988 (Table 1). This is because one man with a height of $103.4 \mathrm{~cm}$ was excluded from the final dataset. It is assumed that such short stature cannot have been due to environmental factors and must have been the result of disease. One point that needs to be stressed is that the dataset we constructed does not seem to suffer from any serious bias. As far as height distribution is concerned, our dataset follows a quasi-normal distribution and, perhaps more importantly, the distribution of heights is very similar to that found for the town of Igualada, which includes all the enlisted young males in the cohorts under consideration. The mean and median are practically the same in both series (Figure 3 ). The dataset we use in this article is also able to mirror the basic occupational structure of an industrial town like Igualada, which, of course, was mostly oriented towards the secondary sector. To give just one example, the population census of 1860 shows that $16.0 \%$ of Igualada's men worked in the primary sector, whereas $78.8 \%$ were employed in the secondary sector; the remaining $5.2 \%$ had jobs in the tertiary sector (Pascual, 2000). This occupational distribution is similar to that resulting from our dataset (Table 2, 
Panel 5). In addition, our dataset captures structural changes in the town during the period under consideration (Pascual, 1991), namely the relative increase in non-agricultural occupations and the relative growth of manual jobs and the tertiary sector. Finally, our dataset captures within-sector changes. For example, for the secondary sector it shows the key importance of textile manufacturing in the mid decades of the nineteenth century, but also the growth and eventual predominance of the tanning industry after World War I (Pascual, 1991). Note, also, that it is able to reflect the expected improvement in human development indicators, such as literacy, from the mid-nineteenth century onwards (Table 2, Panel 4).

Whereas our dataset seems to mirror rather well some of the basic characteristics of the male population in Igualada, the information it contains is not entirely free of potential shortcomings. The first of these derives from the age at which the men were recruited. In Spain, the military authorities modified the enlistment age on several occasions throughout our period of study. For the cohorts born in the period 1845-1850, the age of recruitment was established at 20 years, whereas it was 19 years in the birth cohorts of 1875-1880 and 21 years for the recruits born between 1905 and 1910 (e.g. Cámara, 2006). These modifications in the age of recruitment have implications for the construction of height series and may bias the final results. Whereas we can control for age variations in regression analyses, this is not the case when we construct figures in which data is pooled regardless of the year of recruitment, as in the next section. In order to overcome this problem, and when necessary, we standardised the heights of draftees at the age of 21 years for the periods in which a different recruitment age was established by following the procedure described in J.M. Ramon-Muñoz (2009) and Ramon-Muñoz and Ramon-Muñoz (2016, in press). This procedure, which for reasons of data availability is very simple, can be summarised as follows. First, we took the fiftieth percentile in height of the different groups of cohorts of recruits measured at different ages. Second, we calculated the absolute variation of the fiftieth percentile height across the different age cohorts. Third, we applied these variations to the corresponding cohorts in order to standardise heights. ${ }^{6}$ 
The second potential shortcoming has to do with the method we used to obtain information on some basic features of the recruits' households. Unfortunately, knowledge is still lacking regarding many aspects of the lives of the inhabitants of Igualada between the mid-nineteenth century and the early twentieth century. In addition, we have been unable to apply family reconstitution techniques which, among other things, would have provided evidence on the exact number of members in a family from the time of its constitution. Consequently, we have had to settle for the use of benchmark years by making use of population censuses, from which we derived the structure of the recruits' families at a certain point in time; this approach has been used by other historical studies examining the relationship between sibship size and height (e.g. Hatton, 2015). In our case, we used the local population censuses of 1860,1890 and 1920.

We are well aware that the use of this method means a loss of information and might introduce some bias into our results. Although it allows us to identify the number of siblings alive and present in a given household in the respective census years, it does not provide any information about those siblings who might have died during the first years of life and before the year of census. As a result, we might be underestimating the effect of resource competition among siblings. This potential underestimation may be more problematic in the early years of our study, when infant mortality rates were comparatively higher (Ramon- Muñoz \& Ramon-Muñoz, 2015). It might also be important for those socioeconomic groups experiencing higher mortality rates. Finally, the use of this method to obtain information on recruits' households prevents us from saying anything about those family members who might have abandoned the household during the first 10 years of the recruit's life, and this is another potential source of underestimation. All these potential shortcomings should be borne in mind when interpreting the results.

\section{A complex relationship between sibship size and height}

The resource dilution hypothesis predicts an inverse relationship between sibship size and height. The aggregate data on height and marital fertility presented in Section 2 (Figure 2) suggested that this might have been the case for nineteenth-century Igualada. 
Recent historical research related to other geographical locations has arrived at similar conclusions, but it has also suggested a rather complex relationship between sibship size and height. ${ }^{7}$

[Figure 4 about here]

The dataset we constructed by collecting micro-level data for the Catalan town of Igualada likewise reflects this complexity (Figure 4). Whereas when taking the period $1860-1920$ as a whole the expected negative link is observed for draftees when there are up to four siblings, the opposite holds true with higher numbers of siblings. This is a rather surprising pattern, since one would not expect to find shorter young males in single-child families than in multi-child families. One explanation might be that single births can be the consequence of poor parental health (e.g. Öberg, 2015). However, to our knowledge it is rare in nineteenth- century and early twentieth-century western Europe to find the tallest young males in the largest sized families.

To add further complexity to this picture, the pattern of the relationship between sibship size and height differs across the three benchmark periods for which we have collected data. In the 1860 census, the draftees with no siblings were taller than the rest of their peers. By contrast, the young males that had one or two siblings were shorter than those who had more than two brothers or sisters, suggesting a lack of a negative (linear) correlation between sibship size and the stature of young males. This is not totally the case, however, in the census year of 1890 . According to the available information for this year, the height of young males increases as sibship size decreases, although only until a certain threshold level (i.e. four siblings per draftee). The census year of 1920 shows yet another pattern, namely a kind of curvilinear relationship between sibship size and height. However, and in contrast to both what the data for 1890 show and what the resource dilution hypothesis would predict, this relationship is positive.

These patterns are puzzling and difficult to interpret. One possibility is to link them to the different phases of the fertility transition in Igualada. For example, the surprising results for the early twentieth century may suggest that the relationship between sibship size and height no longer held as the demographic 
transition reached its later stages. They might also indicate that the impact of sibship size on height was affected by many other factors, including the occupation of the parents and, therefore, their socioeconomic status.

In fact, though provisional and fragmentary, there is evidence to suggest that the reduction in family size in Igualada between 1860 and 1890 differed from one socioeconomic group to another. An obvious question, therefore, is whether these differences by social and economic status can also be found when investigating the relationship between sibship size and height. Figure 5 seeks to answer this question by combining the available evidence on heights with information regarding the number of siblings alive in the family in which the recruit grew up and the socioeconomic status of the recruit's father (in terms of occupation). Relying on the HISCO/HISCLASS classification and its adaption to Catalonia by Pujadas-Mora, Romero-Marín, and Villar (2014), we proxy the socioeconomic status of the family through the occupation of the recruit's father and the father's work skills. We focus solely on three different socioeconomic groups in order to avoid categories with a low number of observations, i.e. non-manual workers, highand medium-skilled manual workers (in both the primary and secondary sectors), and low-skilled and unskilled manual workers (also in the primary and secondary sectors).

[Figure 5 about here]

A clear picture emerges from Figure 5. First, it shows that the impact of sibship size on height was rather heterogeneous and varied, depending on the socioeconomic status of the family (as measured by the occupation of the recruit's father).

Second, it suggests that the inverse relationship between sibship size and height is onlyclearly found among those families in which the conscript's father was employed in a highormedium-skilled manual job (as well as among those families in which the occupation ofthe conscript's father was unknown). Interestingly, the families that comprise this formersocioeconomic group mainly belonged to the middle classes of Igualada, since they weremostly farmers with small or medium-sized holdings or traditional urban professionals suchas woodworkers, bricklayers, shoemakers, 
coopers, bakers or locksmiths.

The third observation is that the results are mixed for the remaining socioeconomic groups. In families where the father was a low-skilled or unskilled manual worker, the height of recruits decreased slightly as the number of siblings increased, but again only until a total of four brothers and sisters. Moreover, and contrary to what the resource dilution hypothesis claims, the relationship between sibship size and height was positive in those families where the recruit's father had a non-manual job. This group was almost completely formed by high- and medium-skilled workers and included the upper classes of our dataset, such as industrialists, general managers, notaries or physicians. In our dataset the young males of these latter classes were, on average, taller than an average Igualada recruit, although much less so than would be expected. ${ }^{8}$

[Figure 6 about here]

In order to complement the previous analysis, we have combined data on heights and the number of siblings alive in the family in which the recruit was raised with the occupation of the recruit's father, differentiating now by sector, i.e. primary, secondary and tertiary. The results are presented in Figure 6 and, in general, do not differ greatly from those shown in Figure 5. As in this latter case, the relationship between sibship size and height differs by sector of occupation. In families where the father worked in the tertiary sector and, therefore, generally had a non-manual occupation, this relationship was positive. Of the recruits whose fathers were employed in the primary and secondary sectors, perhaps the most salient feature is that the inverse relationship between sibship size and height seems stronger among the offspring of primary-sector workers. Nevertheless, even in this latter case the heights of the draftees with no siblings were almost the same as those with one or two siblings.

These findings provide further evidence as to the complex nature of the relationship between sibship size and height. Not only do these results call into question once again the general validity of the resource dilution hypothesis over time, across space and between socioeconomic groups, but they suggest that confounding 
factors should probably be taken into consideration when assessing the impact of sibship size on height.

\section{Testing the impact of sibship size on height}

In order to test the link between sibship size and height we have constructed a basic econometric model. This model includes the height of young males as the dependent variable and sibship size as the explanatory variable (and the main variable of interest). As explained in section 3, the height data for draftees have not been standardised in the regressions since we can control for conscript age at the year of inspection. It is worth noting that, in our case, controlling for the age of inspection means also controlling for census year as there is a correspondence between these two variables. In other words, all the draftees that we matched to the population census of 1860 had been inspected at the age of 20 years, whereas those linked to the censuses of 1890 and 1920 had been measured at the ages of 19 and 21 years, respectively.

Section 3 also detailed how we have measured sibship size. It is therefore only necessary to add that in our regressions the focal recruit is also included in the calculation of the total number of siblings. This means that we use as a sibship size measure the total number of children present in the family at the time of the population census, rather than the total number of siblings for a given recruit.

Of course, height and sibship size are not the only variables included in the model we have constructed. The previous section has already suggested that in nineteenth-century and early twentieth-century Igualada the relationship between sibship size and height may be influenced by confounding factors. Therefore, we also consider a number of control variables in an attempt to capture specific characteristics at the child, parental and family levels, respectively. The variable that attempts to capture specific child-related characteristics is the birth order of the considered draftee, which in the context of the resource dilution hypothesis might explain differences in access to family resources. Apparently, one might expect a negative sign (e.g. Horton, 1988), although there is evidence that later-borns are not necessarily the most affected by resource handicap (e.g. Hertwig, Davis, \& 
Sulloway, 2002).

The variable used to capture specific parental characteristics is literacy, as a proxy for the educational level of the recruit's parents. This is a dummy variable that takes the value 1 if the recruit's father is able to read and write and the value 0 when this is not the case. A positive sign is expected. Literacy is sometimes considered a proxy for socioeconomic status, on the assumption that education is related to family income, and may also reflect differences in nutritional status (e.g. Riggs, 1994, p. 69). In fact, a large number of historical studies have found that literate males were taller than illiterate males (e.g. Martínez-Carrión \& PucheGil, 2009; Quiroga, 2003, for Spain). Unfortunately, information for the recruit's mother cannot always be obtained from the sources at our disposal.

Finally, a third group of variables seeks to specifically capture the socioeconomic characteristics of the recruit's family. Using the occupation of the recruit's father and following the HISCLASS classification, we distinguish between three socioeconomic groups in the form of dummy variables, namely high- and medium-skilled manual workers, low-skilled and unskilled manual workers, and non-manual workers. We have also created a new group among those observations for which there is no information on the occupation of the father. We also consider the occupation of the recruit's father by sector distinguishing between primary, secondary and tertiary sectors. In this respect, several studies have pointed out that sectoral occupation, mainly in the primary sector, might be a confounding factor in relation to the influence of sibship size on child outcomes (e.g. Bras et al., 2010).

$$
\mathrm{HEIGHT}_{\mathrm{jt}}=\beta_{0}+\beta_{1} \mathrm{SIBSIZE}_{\mathrm{jt}}+\beta^{\prime}{ }_{2} Z_{j t}+\mu_{i j t}
$$

Equation (1) summarises the basic model to be estimated, which underpins all the regressions in this article. It includes the height of recruit $j$ in year $t\left(\mathrm{HEIGHT}_{\mathrm{jt}}\right)$ as a dependent variable, the number of siblings of recruit $j$ in year $t$ (SIBSIZE $\mathrm{S}_{\mathrm{jt}}$ ) as the main independent variable, a series of control variables designated as $Z_{\mathrm{jt}}$, and, finally, the error term $\mu_{\mathrm{ijt}}$. The model has an additional characteristic. We are aware that the inclusion of some of the independent variables considered in the model might lead to 
collinearity problems in our regressions. This is the case of birth order, which shows a strong linear correlation with sibship size $(r$ $=0.703, p<0.01$ ), since the probability of children with low birth order being from smaller families is higher than that of children born later in the birth order. In order to avoid this problem, and based on the existing literature, we have calculated the so-called birth order index introduced by Booth and Kee (2009) and recently used by Öberg (2015). This index derives from the following expression: Birth Order Index $(\mathrm{BOI})=$ Birth order / ( (Number of Children +1$) / 2$ ). Interestingly, once the variable for birth order is transformed to the BOI the linear correlation between the new variable and sibship size becomes very low $(r=0.061, p<0.10)$, whereas the opposite holds true for the relationship between birth order and BOI $(r=0.729, p<0.01)$. In other words, by transforming birth order into the BOI we are generating a variable that is more independent from (and less correlated with) the total number of siblings and, when used in the regressions, avoids problems of collinearity.

Another source of collinearity arises from the inclusion of dummy variables, particularly those linked to the occupation of the recruit's father. In this case, we have opted to omit from the regressions the dummy variable for the recruits whose father has a low-skilled and unskilled manual occupation, which has become the reference category. If, instead of omitting this dummy variable, we had omitted other dummies on the occupation of the recruit's father, the final results would not vary substantially. The same procedure has been applied to other variables when necessary.

[Table 3 about here]

The different specifications of the model are presented in Table 3. The results indicate a negative association between sibship size and height, although one that is not statistically significant. This is true for both the bivariate regression (Table 3, Column 1) and when we add to the basic regression control variables that capture the existence of specific characteristics related to recruits, their parents and the families in which they grew up (Table 3, Columns 2 to 4), always controlling for census year and age of inspection. In all these specifications, the time variables are statistically significant and have a negative sign, indicating that the draftees 
inspected at the ages of 19 and 20 years (found in the population censuses of 1890 and 1860, respectively) were shorter than those inspected at the age of 21 years (found in the population census of 1920).

Regarding the results for sibship size, all that can be said is that although this variable never reaches statistical significance the magnitude of its (negative) coefficient tends to vary substantially as more control variables are included in the basic model, suggesting a certain role to confounding factors in the link between sibship size and height. According to our results, one of these factors was literacy, which in our regressions is positively and significantly associated with height. Interestingly, the socioeconomic status of the recruit's father also influenced height (Table 3, Columns 3 and 4), but only when the recruit's father worked in a non-manual activity.

Although the link between sibship size and height was generally negative and lacking in statistical significance, there are exceptions to this rule. Table 3 , Columns 5 and 6 present the output of the regressions that include interactions between the socioeconomic status of the recruit's father and our variable of interest, namely sibship size. These interactions show, for example, whether and to what extent the association between sibship size and height varied depending on the socioeconomic status of the recruit's family. The results show that this association did not change substantially, although the signs did. In other words, for those recruits who grew up in families in which the father was either a high- and mediumskilled manual worker or a non-manual worker the association was not statistically significantly different from those recruits whose father had a low-skilled or unskilled occupation. Nevertheless, in the former case the sign of the association between sibship size and height was negative, whereas in the other two categories it was positive, which is apparently at odds with the resource dilution hypothesis. Certainly, the group of non-manual workers included the upper classes of our dataset, and one might hypothesise that they could afford larger families without reducing the level of either family health care or nutritional consumption. For the group of low-skilled and unskilled manual workers, it is hard to provide any conclusive answer at the present state of research. The lack of 
statistical significance of the interactions between the socioeconomic status of the recruit's father and our variable of interest prevents us from commenting further on this issue.

We have complemented this analysis by considering the economic sector in which the recruit's father worked instead of the socioeconomic status of the recruit's father. The results, which are presented in the Appendix section of this article (Table A1), tend to confirm what has been said above. For example, they again show that for those recruits whose father worked in the tertiary sector (mostly non-manual workers) the association between height and sibship size was positive, but also statistically different from the association of the draftees whose father worked in the primary sector, which seems to provide further evidence in support to what has been hypothesised above for the group of non-manual workers.

Although the results presented in Table 3 show that the impact of sibship size on height was rather limited in Igualada, it remains unclear whether it varied over time. With the aim of shedding some light on this issue, we ran a regression to capture changes over time. ${ }^{9}$ The results, which are displayed in the Appendix section of this article (Table A2), suggest that the association between sibship size and height changed over time, being negative in 1860 and 1890 but becoming positive in 1920. However, this association was never statistically significant, and this makes it difficult to comment further on how the link between sibship size and height may have changed. ${ }^{10}$ The lack of statistical significance also applies to most of the other control variables considered in the regression, including literacy, whose statistical significance was apparent in regressions with pooled data.

We obtain similar results when in the regression model we distinguish by both years and socioeconomic groups. ${ }^{11}$ The outcomes of the regressions made it clear that, leaving aside time variables in the pooled regressions, most of the variables considered in our model did not affect the height of recruits throughout the period $1860-1920 .^{12}$ There are only three exceptions to this general rule. ${ }^{13}$ The first two refer to recruits who grew up in families in which the father was a low-skilled or unskilled manual worker in 1860. In this particular year and 
socioeconomic group, the recruits who were born later within the family, as measured by the BOI index, were substantially shorter than were the rest, whereas they were substantially taller if their fathers were able to read and write. The same does not apply to other socioeconomic categories or to other time periods.

[Table 4 about here]

The third exception has to do with our main variable of interest and refers to those recruits whose father had a high- or mediumskilled manual job, which as has already been pointed out, comprises a group of mostly middle-class families (Table 4). For 1890 the results of our regressions show a negative sign for sibship size and a statistical significance at the $10 \%$ confidence level $(p$ $<0.10$ ). This is an interesting finding, but one that is difficult to interpret at the present stage of research. Although the average number of children per family was relatively high in this social group (3.6), it might be hypothesised that some of the group's members were well aware of the potential gains associated with the limitation of family size. One might also speculate that this likely awareness emerged only in the final decades of the nineteenth century, the period when fertility decline accelerated in Igualada and economic growth resumed in the town. Whatever the case, the results show that for this group and year the higher the number of children and siblings in a family, the lower the height reached by the focal recruit.

Taken together, the results discussed in this section mostly confirm the descriptive information presented in previous sections. They certainly suggest a complex relationship between sibship size and height which varied over time and across socioeconomic groups. Ultimately, height was determined by a number of factors, which could enhance or confound the link between sibship size and height depending on the historical context and the social class. All in all, however, the link between sibship size and height was rather weak and, in most cases, non-existent, suggesting that the improvements in biological living standards in Igualada after the 1860s should be attributed to other factors rather than to fertility decline and family size. 


\section{Conclusions}

The resource dilution hypothesis suggests an inverse association between sibship size and the biological standard of living. This article has investigated whether and to what extent this was the case in a medium-sized industrial town in Catalonia during the last third of the nineteenth century and the first decades of the twentieth century. Relying on military records and population censuses, the study has made use of a new dataset on the height of young males recruited in the late $1860 \mathrm{~s}$, the late $1890 \mathrm{~s}$ and the years around 1930, combining this with household information obtained from the population censuses of 1860, 1890 and 1920. To our knowledge, this is the first time that the relationship between sibship size and biological living standards has been analysed in Iberia through the use of longitudinal data at the household level for cohorts born between the 1840s and the 1910s.

The results presented in this article show that the impact of sibship size on child outcomes, as hypothesised by the resource dilution explanation, was rather weak during the years of the first fertility transition. Furthermore, when such an impact was observed it was sometimes at odds with expectations. According to the econometric results, the effect of sibship size on height was negative and statistically significant $(\mathrm{p}<0.10)$ only among those young males whose father had a high- or medium-skilled manual job in 1890. By contrast, and against expectations, a positive and statistically significant relationship $(\mathrm{p}<0.05)$ between sibship size and height was found for those conscripts whose father worked in the tertiary sector, mostly formed by non-manual workers. In other words, sibship size only affected the height of young males in certain socioeconomic groups and in specific periods of time, and not always in the expected direction. The econometric analysis also showed statistically significant differences when taking literacy into account, at least when this was proxied by the literacy level of the conscript's father and when the data for the period 1860-1920 were pooled. Thus, those recruits who grew up in families in which the father was able to read and write were, on average, notably taller than those whose father was illiterate.

Recent historical studies based on household data for northwestern Europe have shown a negative impact of sibship size on 
height for the period between the last years of the nineteenth century and the first two or three decades of the twentieth century. The evidence presented in this article suggests a different pattern for some regions of southern Europe, although this statement must be qualified in two respects. First, the results refer solely to a single locality, the Catalan town of Igualada. Although representative of factory-based industrialisation, the town's pattern of growth, decline and recovery cannot be fully generalised to other areas of Catalonia during the mid-nineteenth century and the early twentieth century. Second, the method used in this study to collect information at the household level is not based on the technique of family reconstitution, and it has therefore not been possible to fully capture all the life events that may occur in a household. This latter aspect means that caution must be exercised when interpreting the results.

Although limited in many respects, this study has delved into the complex nature of the relationship between sibship size and height. The analysis suggests that although weak, this relationship varied over time and across socioeconomic groups, and that it might be conditioned by a number of confounding factors. In fact, the educational level of the parents appears to have been more important than sibship size in explaining the heights of young males. Interestingly, for the group of high- and medium-skilled manual workers, the inverse association between sibship size and height was observed in the central years of the first fertility transition, but not before or after. In addition, it seems unlikely that resource dilution through family size had limited the height of young males from the most well-off sectors of society. Whereas several factors influenced child outcomes over time and across socioeconomic groups, the evidence and analysis presented in this article also show that the impact of sibship size on the biological living standards of young males was generally statistically nonsignificant. Assessing whether these findings can be extended to other areas of Catalonia and southern Europe is the next step of our research.

\section{Notes}

1. The notion of quality-quantity trade-off refers to the fact that 'a family must determine not only how many children it has but also the 
amount spent on them' (Becker, 1960, p. 211; see also Becker \& Lewis, 1973; Becker \& Tomes, 1976). In addition, it argues that the relationship between the number (quantity) of children ever born to a family and the amount spent on them (quality) tends to be negative; it also suggests that the increase in per capita income triggers fertility decline. Recently, Brezis and Dos Santos (2015) added a negative sibship size effect to the Beckerian model of endogenous fertility. Focusing on the determinants of modern economic growth, unified growth theory places the child quality-quantity trade-off at the centre of the explanation for the transition from stagnation to growth (Galor, 2005, 2011; Galor \& Weil, 2000). Contrary to Becker (1960) and other scholars, this theory suggests that the fertility decline in the late nineteenth century and the transition to modern growth can be explained in terms of the demand for human capital (Galor, 2012).

2. Previous historical research also includes, among others, the works by Adams and Kasakoff (1992), Weir (1993) and Wall (1996).

3. In Catalonia, and across Spain, a person's full name consists of a forename (single or composite) followed by two surnames. As a general rule, the first surname is the father's first surname, while the second is the mother's first surname. Although the use of both the father's and mother's surnames was customary much earlier, it was during the last decades of the nineteenth century that this customary tradition became mandatory, with the establishment of the Civil Registry in 1871 (e.g. Mateos \& Tucker, 2008). Note also that, in contrast to many countries, Catalan and Spanish women do not change their two surnames when they marry.

4. Unfortunately, the population censuses available for the mid decades of the nineteenth century did not indicate - at least in Igualada - the place and date of birth of the household members, although their age was detailed. The home address of the household members at the time of the census was not provided either. Nonetheless, the censuses grouped the inhabitants of Igualada by household, although without detailing the particular position each household member occupied.

5. These linkage rates are similar to those obtained in Sweden by Öberg (2015) in matching conscripts with family information between the late eighteenth and mid-twentieth centuries. In contrast, they are higher than those presented in studies documenting intergenerational mobility in the USA in the nineteenth and the first third of the twentieth centuries. These studies are able to match no more than $25 \%$ of the population (e.g. Abramitzky, Boustan, \& Eriksson, 2014; Collins \& Wanamaker, 2014; Hornbeck \& Naidu, 2014; Long \& Ferrie, 2013). To our knowledge, exceptions to this rule are Feigenbaum (2016) for the State of Iowa between 1915 and 1940 (nearly $60 \%$ of matching success), Nix and Qian (2015) for the USA 
between 1880 and 1940 (around 61-67\%) and Eriksson (2015) for Sweden between 1880 and 1900 (60-76\%, depending on the period).

6. Having said this, we are, nevertheless, aware that our height data do not fully capture adult height but rather show the height of young males at the time of inspection. We assume that the draftees in our dataset might continue to grow after the date of inspection, as well as when they enlisted at the age of 21 years. This seems particularly true for those draftees who had suffered deprivation in the past. Therefore, it is worth noting that our data reflect the nutritional experience as well as the living conditions of young males until the moment they were inspected for military service. This past experience and the possible influence of sibship size on the biological conditions of young males are at the centre of the present research.

7. See the introductory section of this article for references.

8. See, for example, the recent article by Öberg (2014), who also reviews the historical literature on socioeconomic differences in height.

9. We regressed height against sibship size, together with the set of variables constructed to capture the personal, parental and socioeconomic characteristics of the recruit's family. We also included interactions between time periods and the rest of the variables in order to capture changes over time.

10.If we had included in the regressions the economic sector in which the recruit's father worked instead of the socioeconomic status of the recruit's father, the results (not shown) would have been very similar, at least in terms of statistical significance and the sign of the considered variables.

11.The results are presented in Table 4 and in the Appendix section of this article (Table A3). In these cases, we had to exclude from our analysis those young males belonging to both families in which the father had a non-manual occupation in 1860 and families in which the father's occupation in 1860 was not known, due to the low number of observations for some of the considered years. The econometric strategy was also different to that followed in the previous regressions: first, we ran independent regressions according to both the focal year and the focal socioeconomic group; second, we used as control variables the birth order index and the father's literacy. In addition, we included pooled regressions by socioeconomic group, controlling now for age of inspection and census year. The coefficients for literate father have to be interpreted relative to the rest of the literacy groups, namely illiterate father and unknown literacy status of the father. For those recruits whose father was a non-manual worker, literacy variables are not reported owing to the low number of conscripts whose fathers were illiterate or had an unknown literacy 
status. In fact, in 1890 all non-manual workers in our sample were literate and in 1920 only two out of 59 non-manual workers did not belong to the category of literate men. The low number of observations for certain periods and socioeconomic categories may also affect the results, particularly in the pooled regressions.

12.Furthermore, whereas the coefficients of our variable of interest vary over time and across socioeconomic groups, these variations do not seem to differ significantly from one period and group to another. In particular, this is shown in Table 3 (Columns 5 and 6) and Table A2 (interactions).

13. Only one (albeit non-negligible) exception would be reported if instead of running regressions using the socioeconomic status of the recruit's father as control variable we had used the economic sector in which the recruit's father worked, namely a positive and statistically significant relationship $(\mathrm{p}<0.05)$ between sibship size and height for those recruits whose fathers worked in the tertiary sector.

\section{Acknowledgements}

We would like to thank Stefan Öberg for his help and interesting suggestions relating to earlier versions of this paper. We also would like to thank the participants in the workshop 'Health and Welfare in the long run' (Groningen, 2016), the Thirty-sixth Health Economics Association Conference (AES) (Murcia, 2016), and the Eleventh Conference of the Iberian Society of Historical Demography (ADEH) (Cádiz, 2016), in particular Josep Bernabeu, Elise Brezis, Bernard Harris, Vicente Pérez Moreda, Lucia Pozzi, Marisol Rodríguez, and Eric Schneider, and the anonymous referees of this journal for their useful comments. We are also grateful to the staff of the Arxiu Comarcal de l'Anoia (Anoia County Archive) for their kind collaboration and to Montse Escudé, Júlia Ramon and Guillem Ramon for their help in the construction of the dataset. The usual disclaimer applies.

\section{Disclosure statement}

No potential conflict of interest was reported by the authors.

\section{Funding}

We acknowledge funding support from Spain's Ministry of 
Economy and Competitiveness (MINECO) through projects [HAR2013-47182-C2-2-P] and [MINECO/FEDER, UE HAR2015-64769-P], as well as from the Fundación Séneca. Agencia de Ciencia y Tecnología de la Región de Murcia, through project [19512/PI/14].

\section{References}

Abramitzky, R., Boustan, L. P., \& Eriksson, L. (2014). A nation of immigrants: Assimilation and economic outcomes in the age of mass migration. Journal of Political Economy, 122, 467506. doi:10.1086/675805

Adams, J. W., \& Kasakoff, A. B. (1992). The farm family economy in the American north, 1775- 1875: An exploration of sibling differences. Continuity and Change, 7, 357-375. doi:10.1017/S0268416000001715

Angrist, J., Lavy, V., \& Schlosser, A. (2010). Multiple experiments for the causal link between the quantity and quality of children. Journal of Labor Economics, 28, 773824. doi: $10.1086 / 653830$

Bailey, R. E., Hatton, T. J., \& Inwood, K. (2016). Health, height and the household at the turn of the 20th century. Economic History Review, 69, 35-53. doi:10.1111/ehr.12099

Becker, G. S. (1960). An economic analysis of fertility. In G. S. Becker (Ed.), Demographic and economic change in developed countries (pp. 209-240). Princeton: Princeton university Press.

Becker, S., Cinnirella, F., \& Woessmann, L. (2010). The trade-off between fertility and education: Evidence from before the demographic transition. Journal of Economic Growth, 15, 177-204. doi:10.1007/s10887-010-9054-x

Becker, G. S., \& Lewis, H. G. (1973). on the interaction between the quantity and quality of children. Journal of Political Economy, 81, S279-S288. doi: 10.1086/260166

Becker, G. S., \& Tomes, N. (1976). Child endowments and the quantity and quality of children. Journal of Political Economy, 84, S143-S162. doi: 10.1086/260536

Benavente, J. (1989). Social change and early fertility decline in Catalonia. European Journal of Population, 5, 207-234. doi:10.1007/BF01796817 
Benavente, J. (1990). La minva de la fecunditat a Catalunya [The fertility decline in Catalonia]. In J. nadal (Dir.), Història econòmica de la Catalunya contemporània, 2: Segle XIX. Població $i$ agricultura (pp. 63-119). Barcelona: Enciclopèdia Catalana.

Black, S. E., Devereux, P. J., \& Salvanes, K. G. (2005). The more the merrier? The effect family size and birth order on children's education. Quarterly Journal of Economics, 120, 669-700. doi:10.1093/qje/120.2.669

Blake, J. (1981). Family size and the quality of children. Demography, 18, 421-442. doi:10.2307/2060941

Blake, J. (1989). Family size and achievement. Berkeley: university of California Press.

Bleakley, H., \& Lange, F. (2009). Chronic disease burden and the interaction of education, fertility, and growth. Review of Economics and Statistics, 91, 52-65. doi:10.1162/rest.91.1.52

Boberg-Fazlic, n. P., Sharp, P. R., \& Weisdorf, J. (2011). Survival of the richest? Social status, fertility, and social mobility in England 1541-1824. European Review of Economic History, 15, 365-392. doi:10.1017/S136149161100013X

Booth, A. L., \& Kee, H. J. (2009). Birth order matters: The effect of family size and birth order on educational attainment. Journal of Population Economics, 22, 367-397. doi:10.1007/s00148-007-0181-4

Bras, H., Kok, J., \& Mandemakers, K. (2010). Sibship size and status attainment across contexts: Evidence from the netherlands, 1840-1925. Demographic Research, 23, 73104. doi: 10.4054/DemRes.2010.23.4

Brezis, E. S., \& Dos Santos Ferreira, R. (2015). Endogenous fertility with a sibship size effect. Macroeconomic Dynamics. Available on CJo2015. doi:10.1017/S1365100515000255

Buchmann, C., \& Hannum, E. (2001). Education and stratification in developing countries: A review of theories and research. Annual Review of Sociology, 27, 77-102. doi:10.1146/annurev.soc.27.1.77

Cabré, A. (1999). El sistema català de reproducció [The Catalan reproduction system]. Barcelona: Proa.

Cámara, A. D. (2006). Fuentes antropométricas en España: 
problemas metodológicos para los siglos XVIII y XIX [Anthropometric sources in Spain: methodological problems in the eighteenth and nineteenth centuries]. Historia Agraria, 38, 105-118. Retreived from http://www.historiaagraria.com/articulo.php?id=411\&num $=3$ $\underline{8}$

Cámara, A. D. (2007). Niveles de vida en el medio rural de Andalucía Oriental (1750-1950) [Living Standards in rural Eastern Andalusia (1750-1950)]. Granada: Editorial de la universidad de Granada.

Camps, E. (1995). La formación del mercado de trabajo industrial en la Cataluña del siglo XIX [The formation of the industrial labour market in Catalonia in the nineteenth century]. Madrid: Ministerio de Trabajo y Seguridad Social.

Clark, G., \& Hamilton, G. (2006). Survival of the richest: The malthusian mechanism in pre-industrial England. The Journal of Economic History, 66, 707-736. doi:10.1017/S0022050706000301

Coale, A. J. (1986). The decline of fertility in Europe since the eighteenth century as a chapter in human demographie history. In A. J. Coale \& S. C. Watkins (Eds.), The decline of fertility in Europe (pp. 1-30). Princeton: Princeton university Press.

Collins, W. J., \& Wanamaker, M. H. (2014). Selection and economic gains in the great migration of african Americans: new evidence from linked census data. American Economic Journal: Applied Economics, 6, 220-252. doi:10.1257/app.6.1.220

Craig, L. A. (2016). nutrition, the biological standard of living, and cliometrics. In C. Diebolt \& M. Haupert (Eds.), Handbook of cliometrics (pp. 113-130). Heidelberg: Springer.

Cummins, n. (2013). Marital fertility and wealth during the fertility transition: Rural France, 1750-1850. Economic History Review, 66, 449-476. doi:10.1111/j.1468-0289.2012.00666.x

Desai, S. (1995). When are children from large families disadvantaged? Evidence from cross-national analyses. Population Studies, 49, 195-210. doi:10.1080/0032472031000148466

Downey, D. B. (1995). When bigger is not better: Family size, parental resources, and children's educational performance. 
American Sociological Review, 60, 746-761. doi: $10.2307 / 2096320$

Downey, D. B. (2001). number of siblings and intellectual development: The resource dilution explanation. American Psychologist, 56, 497-504. doi:10.1037/0003-066X.56.67.497

Dribe, M., \& Scalone, F. (2014). Social class and net fertility before, during, and after the demographic transition: A micro-level analysis of Sweden 1880-1970. Demographic Research, 30, 429-464. doi: 10.4054/DemRes.2014.30.15

Eloundou-Enyegue, P. M., \& Williams, L. B. (2006). Family size and schooling in sub-saharan african settings: A reexamination. Demography, 43, 25-52. doi: $10.1353 / \mathrm{dem} .2006 .0002$

Eriksson, B. (2015). Dynamic decades. A micro perspective on late nineteenth century Sweden. Lund: Lund university.

Feigenbaum, J. J. (2016). Automated census record linking: A machine learning approach. Harvard university. (Working Paper). Harvard university. Retreived from http://scholar.harvard.edu/files/jfeigenbaum/files/feigenbaum -censuslink.pdf

Fernihough, A. (2011). Human capital and the quantity-quality trade-off during the demographic transition: New evidence from Ireland (Working paper no. 11/13). University College Dublin.

Retrieved from http://researchrepository.ucd.ie/bitstream/handle/10197/6389 /WP11_13.pdf? sequence $=1$

Floud, R., Fogel, R. W., Harris, B., \& Hong, S. C. (2011). The changing body. Health, nutrition, and human development in the western world since 1700. Cambridge: Cambridge University Press.

Galor, O. (2005). unified growth theory: From stagnation to growth. In P. Aghion \& S. Durlauf (Eds.), Handbook of economic growth. Volume la (pp. 171-293). Amsterdam: north-Holland. doi: 10.1016/S1574-0684(05)01004-X

Galor, O. (2011). Unified growth theory. Princeton: Princeton university Press.

Galor, O. (2012). The demographic transition: Causes and consequences. Cliometrica, 6, 1-28. doi:10.1007/s11698$\underline{011-0062-7}$ 
Galor, O., \& Weil, D. N. (2000). Population, technology, and growth: From Malthusian stagnation to the demographic transition and beyond. American Economic Review, 90, 806828. doi:10.1257/aer.90.4.806

Gil Alonso, F. (2007). Women who controlled their fertility and women who did not: An analysis of women's fertility behaviour in late 19th and early 20th Century Spain. In A. Janssens (Ed.), Gendering the fertility decline in the western world (pp. 85-112). Bern: Peter Lang.

Guinnane, T. W., Okun, B. S., \& Trussell, J. (1994). What do we know about the timing of fertility transitions in Europe? Demography, 31, 1-20. doi:10.2307/2061905

Guo, G., \& Van Wey, L. K. (1999). Sibship size and intellectual development: Is the relationship causal?American Sociological Review, 64, 169-187. doi:10.2307/2657524

Hatton, T. J. (2015). Stature and sibship: Historical evidence. (Working Paper no. 2015-09). Centre for Economic History. The Australian national university. Retrieved from https://www.cbe.anu.edu.au/researchpapers/ceh/WP201509.p $\underline{\mathrm{df}}$

Hatton, T. J., \& Martin, R. M. (2010a). Fertility decline and the heights of children in Britain, 1886-1938.Explorations in Economic History, 47 , 505-519. doi:10.1016/j.eeh.2010.05.003

Hatton, T. J., \& Martin, R. M. (2010b). The effects on stature of poverty, family size, and birth order: British children in the 1930s. Oxford Economic Papers, 62, 157-184. doi:10.1093/oep/gpp034

Hertwig, R., Davis, J. n., \& Sulloway, F. J. (2002). Parental investment: How an equity motive can produce inequality. Psychological Bulletin, 128, 728-745. doi:10.1037/00332909.128.5.728

Hornbeck, R., \&Naidu, S. (2014). When the levee breaks: Black migration and economic development in the American south. American Economic Review, 104, 963-990. doi:10.1257/aer.104.3.963

Horton, S. (1988). Birth order and child nutritional status: Evidence from the Philippines. Economic Development and Cultural Change, 36, 341-354. doi:10.1086/451655

Kessler, D. (1991). Birth order, family size, and achievement: 
Family structure and wage determination.Journal of Labor Economics, 9, 413-426. doi:10.1086/298275

Kippen, R., \& Walters, S. (2012). Is sibling rivalry fatal? Siblings and mortality clustering. Journal of Interdisciplinary History, 42, 571-591. doi:10.1162/JInH_a_00305

Klemp, M. P. B., \& Weisdorf, J. (2012). Fecundity, fertility and family reconstitution data: The child quantity- quality tradeoff revisited (Working Paper no. 9121). Centre for Economic Policy Research (CEPR. Retrieved from http://cepr.org/active/publications/discussion_papers/dp.php? dpno $=9121$

Komlos, J. (2004). How to (and how not to) analyze deficient height size samples. Historical Methods, 37, 160-173. doi:10.3200/HMTS.37.4.160-173

Leasure, J. W. (1963). Factors involved in the decline of fertility in Spain 1900-1950. Population Studies, 16, 271-285. doi:10.1080/00324728.1963.10416454

Lee, J. (2008). Sibling size and investment in children's education: An asian instrument. Journal of Population Economics, 21, 855-875. doi:10.1007/s00148-006-0124-5

Livi-Bacci, M. (1968). Fertility and nuptiality changes in Spain from the late 18th to the early 20th century: Part 1. Population Studies, 22, 83-102. doi:10.1080/00324728.1968.10405527

Livi-Bacci, M. (1968). Fertility and nuptiality changes in Spain from the late 18th to the early 20th century: Part 2. Population Studies, 22, 211-234. doi:10.1080/00324728.1968.10405536

Livi-Bacci, M. (1986). Social-group forerunner of fertility control in Europe. In A. J. Coale \& S. C. Watkins (Eds.), The decline of fertility in Europe (pp. 182-200). Princeton: Princeton University Press.

Long, J., \& Ferrie, J. (2013). Intergenerational occupational mobility in Great Britain and the United States since 1850. American Economic Review, 103, 1109-1137. doi:10.1257/aer.103.4.1109

Lu, Y., \& Treiman, D. J. (2008). The effect of sibship size on educational attainment in China: Period variations. American Sociological Review, 73, 813-834. doi: $\underline{10.1177 / 000312240807300506}$ 
Maralani, V. (2008). The changing relationship between family size and educational attainment over the course of socioeconomic development: Evidence from Indonesia. Demography, 45, 693-717. doi:10.1353/dem.0.0013

Marfany, J. (2001). Migración e industrialización en Cataluña a mediados del siglo XIX: Igualada, 1847-59 [The formation of the industrial labour market in Catalonia in the nineteenth century]. (Working Paper no. 200). Papers de Demografia. Centre d'Estudis Demogràfics. Retrieved from http://www.ced.uab.es/publicacions/PapersPDF/Text200.pdf

Martínez-Carrión, J. M., \& Moreno-Lázaro, J. (2007). Was there an urban height penalty in Spain, 1840- 1913? Economics and Human Biology, 5, 144-164. doi:10.1016/j.ehb.2006.09.001

Martínez-Carrión, J. M., Pérez de Perceval, M. A., \& MartínezSoto, A. P. (2014). Desigualdad y bienestar biológico durante el boom minero. Río Tinto, 1836-1935 [Inequality and Biological Welfare during the Mining Boom: Río Tinto, 1836-1935]. (Working Paper no. 1401). Asociación Española de Historia Económica [Spanish Association of Economic History] Retrieved from http://www.aehe.es/wpcontent/uploads/2015/04/dt-aehe-1401.pdf

Martínez-Carrión, J. M., \& Pérez-Castejón, J. J. (1998). Height and standards of living during the industrialisation of Spain: The case of Elche. European Review of Economic History, 2, 201-230. doi:10.1017/S1361491698000094

Martínez-Carrión, J. M., \& Puche-Gil, J. (2009). Alfabetización, bienestar biológico y desigualdad: la Comunidad valenciana, 1850-1970 [Literacy, biological welfare and inequality: region of Valencia, 1850-1970]. Historia Agraria, 47, 167$186 . \quad$ Retreived from http://www.historiaagraria.com/articulo.php?id=539\&num $=4$ $\underline{7}$

Mateos, P., \& Tucker, K. (2008). Forenames and surnames in Spain in 2004. Names: AJournal of Onomastics, 56, 165184. doi: $10.1179 / 175622708 \times 332860$

Murphy, T. E. (2015). Old habits die hard (sometimes). Can département heterogeneity tell us something about the French fertility decline? Journal of Economic Growth, 20, 177-222. doi:10.1007/s10887-015-9111-6 
Nadal, J. (1961). Demografía y economía en el origen de la Cataluña moderna. un ejemplo local: Palamós (1705-1839) [Demography and economy in the origins of modern Catalonia. A local case study: Palamós (1705-1839)]. Estudios de Historia Moderna, 6, 281-309.

Nadal, J. (1975). El fracaso de la Revolución Industrial en España, 1814-1913 [The failure of the industrial revolution in Spain, 1814-1913]. Barcelona: Ariel.

Nadal, J. (1986). La población española (Siglos XVI a XX) [The Spanish population (from the sixteenth to the twentieth centuries]. Barcelona: Ariel.

Nadal, J., \& Sáez, A. (1972). La fécondité à Saint Joan de Palamós (Catalogne) de 1700 à 1859 [Fecundity in Sant Joan de Palamós (Catalonia) from 1700 to 1859]. Annales de Démographie Historique, 1972, 105-113. doi:10.3406/adh.1972.2110

Nicolau, R. (1990). Els factors demogràfics del creixement econòmic: Catalunya, 1787-1910 [The demographic factors in economic growth: Catalonia, 1787-1910]. In J. nadal (Dir.), Història econòmica de la Catalunya contemporània, 2: Segle XIX. Població i agricultura (pp. 13-62). Barcelona: Enciclopèdia Catalana.

Nicolau, R. (1991). Trayectorias regionales en la transición demográfica española [Regional patterns in the Spanish demographic transition]. In M. Livi-Bacci (Ed.), Modelos regionales de la transición demográfica en España y Portugal (pp. 49-65). Alicante: Instituto de Cultura Juan Gil-Albert.

Nix, E., \& Qian, n. (2015). The fluidity of race: "passing” in the United States, 1880-1940. (Working Paper no. 20828). National Bureau of Economic Research (NBER). Retrieved from http://www.nber.org/papers/w20828.pdf

Öberg, S. (2014). Long-term changes of socioeconomic differences in height among young adult men in Southern Sweden, 1818-1968. Economics and Human Biology, 15, 140-152. doi:10.1016/j.ehb.2014.08.003

Öberg, S. (2015). Sibship size and height before, during, and after the fertility decline: A test of the resource dilution hypothesis. Demographic Research, 32, 29-74. doi: 10.4054/DemRes.2015.32.2 
Parman, J. (2015). Childhood health and human capital: new evidence from genetic brothers in arms.The Journal of Economic History, 75, 30-64. doi:10.1017/S0022050715000029

Pascual, P. (1991). Fàbrica i treball a Igualada de la primera meitat del segle $X X$ [Factory and work in Igualada in the first half of the twentieth century]. Barcelona: Ajuntament d'Igualada-Publicacions de l'Abadia de Montserrat.

Pascual, P. (2000). Els Torelló. Una familia igualadina d'advocats i propietaris. Volum 1 [The Torelló. A family of lawyers and landowners. Volume 1]. Barcelona: Fundació Salvador Vives Casajuana-Editorial Rafael Dalmau.

Pollard, S. (1981). The peaceful conquest. The industrialization of Europe 1760-1970. Oxford: Oxford University Press.

Puche-Gil, J. (2011). Evolución del nivel de vida biológico en la Comunidad Valenciana, 1840- 1969 [Evolution of the biological standard of living in the Valencia Region (Spain), 1840-1969]. Investigaciones de Historia Económica, 7, 380394. doi: $10.1016 /$ j.ihe.2010.10.003

Pujadas-Mora, J. M., Romero-Marín, J., \& Villar, C. (2014). Propuestas metodológicas para la aplicación de HISCo en el caso de Cataluña, siglos XV-XX [Methodological proposals for the application of HISCo in the case of Catalonia, from the fifteenth to the twentieth century]. Revista de Demografía Histórica, 32, 181-219. Retreived from https://www.adeh.org/?q=es/system/files/Revista/I2014/RDH $\% 20 X X X I I \% 20 \% 28 I \% 29 \% 202014 \% 20$ Pujadas $\%$ 2C\%20Romero\%20y\%20Villar.pdf

Qian, N. (2009). Quantity-quality and the one child policy: The only-child disadvantage in school enrolment in rural China. (Working Paper no. 14973). National Bureau of Economic Research (NBER). Retrieved from http://www.nber.org/papers/w14973.pdf

Quiroga, G. (2003). Literacy, education and welfare in Spain (1893-1954). Paedagogica Historica, 39, 599-619. doi:10.1080/0030923032000128818

Ramon-Muñoz, R. (2006). El procés d'electrificació de la Igualadina Cotonera (1885-1914) [The process of electrification of the Igualadina Cotonera (1885-1914)]. Miscellanea Aqualatensia, 12, 285-322. Retreived from: 
www.raco.cat/index.php/MiscellaneaAqualatensia/article/do wnload/129859/180175

Ramon-Muñoz, J. M. (2009). Bienestar biológico y crecimiento agrario en la Cataluña rural, 1840-1936 [Biological welfare and agrarian growth in rural Catalonia, 1840-1936]. Historia Agraria, 47, 119-142. Retreived from: www.historiaagraria.com/articulo.php?id=537\&num $=47$

Ramon-Muñoz, R., \& Ramon-Muñoz, J. M. (2015). Height and industrialisation in a city in Catalonia during the nineteenth century. (Working Paper no. E15/334). uB Economics. university of Barcelona. Retreived from http://www.ub.edu/ubeconomics/wpcontent/uploads/2016/01/334WEB.pdf

Ramon-Muñoz, R., \& Ramon-Muñoz, J. M. (2016, in press). The biological standard of living in nineteenth- century industrial Catalonia: A case study. Revista de Historia Industrial.

Razzaque, A., Streatfield, P. K., \& Evans, A. (2007). Family size and children's education in matlab.Bangladesh. Journal of Biosocial Science, 39, 245-256. doi: $10.1017 /$ S0021932006001398

Riggs, P. (1994). The standard of living in Scotland, 1800-1850. In J. Komlos (Ed.), Stature, living standards and economic development. Essays in anthropometric history (pp. 60-75). Chicago, The University of Chicago Press.

Skirbekk, V. (2008). Fertility trends by social status. Demographic Research, 18, 145-180. doi:10.4054/DemRes.18.5

Steelman, L. C., Powell, B., Werum, R., \& Carter, S. (2002). Reconsidering the effects of sibling configuration: Recent advances and challenges. Annual Review of Sociology, 28, 243-269. doi:10.1146/annurev.soc.28.111301.093304

Sudha,S.(1997).Familysize,sexcompositionandchildren'seducation :Ethnicdifferentialsoverdevelopment in peninsular Malaysia. Population Studies, 51, 139-151. doi: $10.1080 / 0032472031000149876$

Térmens, M. (1983). El ferrocarril a Igualada: la lluita pel progrés (1852-1893) [The railway to Igualada: the struggle for progress (1852-1893)]. Miscellanea Aqualatensia, 3, 215245.

Retreived

from:

www.raco.cat/index.php/MiscellaneaAqualatensia/article/do wnload/129887/180377 
Torras, J. (1991). The old and the new. Marketing networks and textile growth in eighteenth-century Spain. In M. Berg (Ed.), Markets and manufacture in early industrial Europe (pp. 93113). London: Routledge.

Torras i Ribé, J. M. (1979). La revolució industrial a la comarca de l'Anoia [The industrial revolution in the county of Anoia]. Barcelona: Rafael Dalmau.

Vallin, J. (2006): Europe's demographic transition, 1740-1940. In G. Caselli, J. Vallin \& G. J. Wunsch (Eds.),Demography: Analysis and synthesis. volume III (pp. 41-66). Amsterdam: Elsevier.

Van Bavel, J. (2006). The effect of fertility limitation on intergenerational social mobility: The quantity- quality trade-off during the demographic transition. Journal of Biosocial Science, 38, 553-569. doi:10.1017/S0021932005026994

Van Bavel, J., Moreels, S., Van de Putte, B., \& Matthijs, K. (2011). Family size and intergenerational social mobility during the fertility transition: Evidence of resource dilution from the city of Antwerp in 19th century Belgium. Demographic Research, 24, 313-344. doi: 10.4054/DemRes.2011.24.14

Van Leeuwen, M. H. D., \& Maas, I. (2011). HISCLASS. A historical international social class scheme. Leuven: Leuven university Press.

Van Leeuwen, M. H. D., Maas, I., \& Miles, A. (2002). HISCO. Historical international standard classification of occupations. Leuven: Leuven university Press.

Van Leeuwen, M. H. D., Maas, I., \& Miles, A. (2004). Creating a historical international standard classification of occupations: An exercise in multinational. Interdisciplinary Cooperation. Historical Methods, 37, 186-197. doi:10.3200/HMTS.37.4.186-197

Wall, R. (1996). Marriage, residence, and occupational choices of senior and junior siblings in the English past. The History of the Family, 1, 259-271. doi:10.1016/S1081-602X(96)90024$\underline{X}$

Weir, D. R. (1984). Fertility transition in rural France, 1740-1829. The Journal of Economic History, 44, 259-274. doi:10.1017/S0022050700032216 
Weir, D. R. (1993). Parental consumption decisions and child health during the early French fertility decline, 1790-1914. The Journal of Economic History, 53, 259-274. doi:10.1017/S0022050700012900

Wrigley, E. A. (1985a). The fall of marital fertility in nineteenthcentury France: Exemplar or exception?(part I). European Journal of Population, 1, 31-60. doi:10.1007/BF01796917

Wrigley, E. A. (1985b). The fall of marital fertility in nineteenthcentury France: Exemplar or exception? (part II). European Journal of Population, 1, 141-177. doi:10.1007/BF01796931

Yu, W.-H., \& Su, K.-H. (2006). Gender, sibship structure, and educational inequality in Taiwan: Son preference revisited. Journal of Marriage and Family, 68, 1057-1068. doi:10.1111/j.1741-3737.2006.00313.x 


\section{Tables and figures}

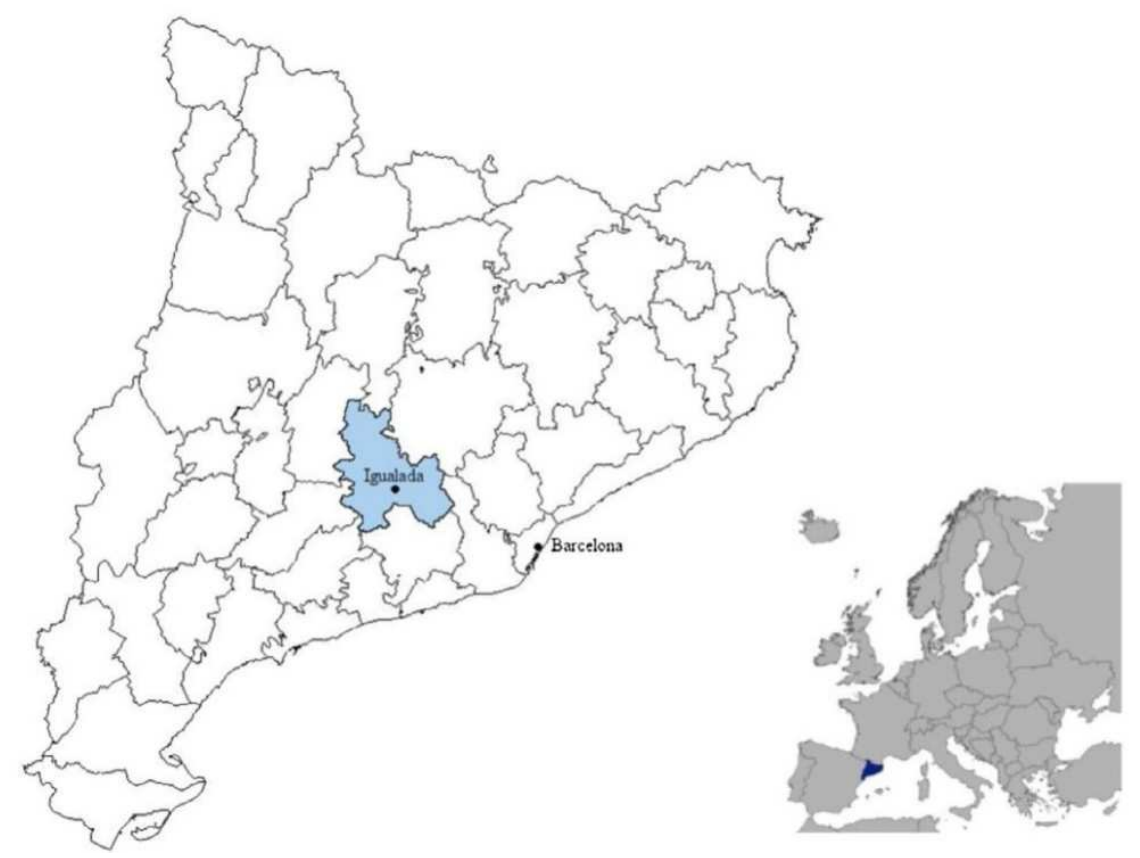

Figure 1. The geographical location of Igualada.

Notes and sources: Based on http://epp.eurostat.ec.europa.eu and http://municat.gencat.cat. 


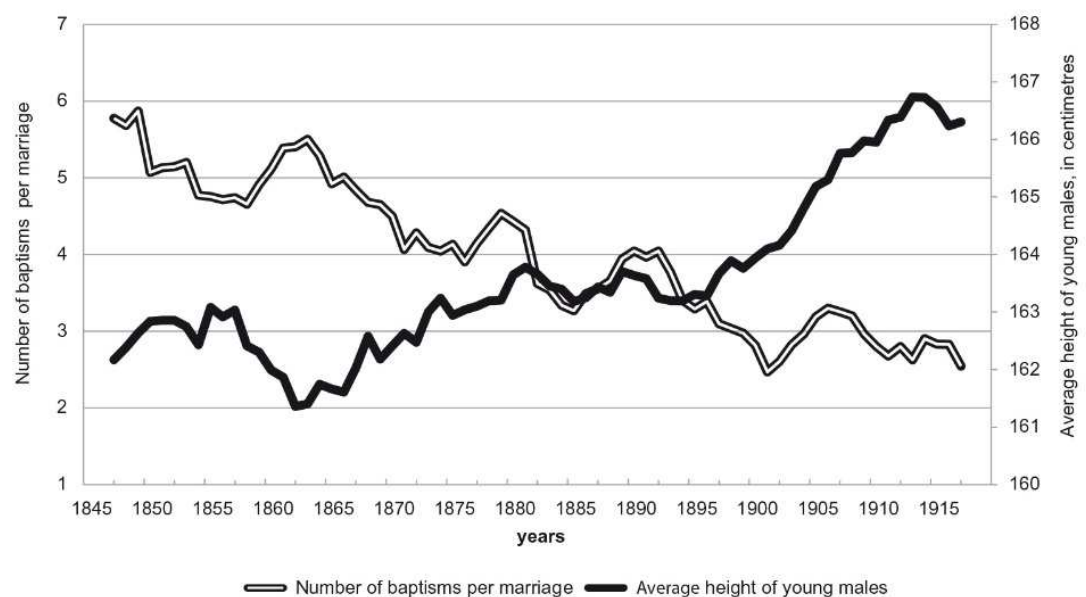

Figure 2. Change in marital fertility rates and the height of young males in Igualada, 1840s-1910s (fiveyear moving averages and heights by birth year).

Notes and sources: The height data refer to the draftees registered as inhabitants of Igualada in their year of conscription. See also Ramon-Muñoz and RamonMuñoz $(2015,2016$, in press). The number of baptisms per marriage has been taken from the baptism and marriage books of the parish of Santa Maria d'Igualada. Arxiu Comarcal de l'Anoia, hereinafter ACAN. 


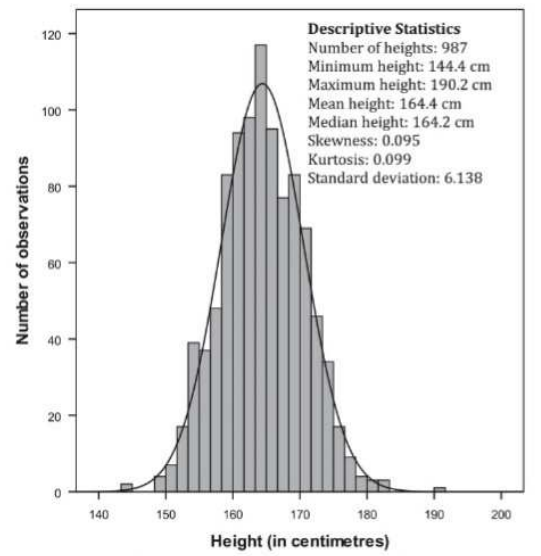

(a) Conscripts included in the dataset

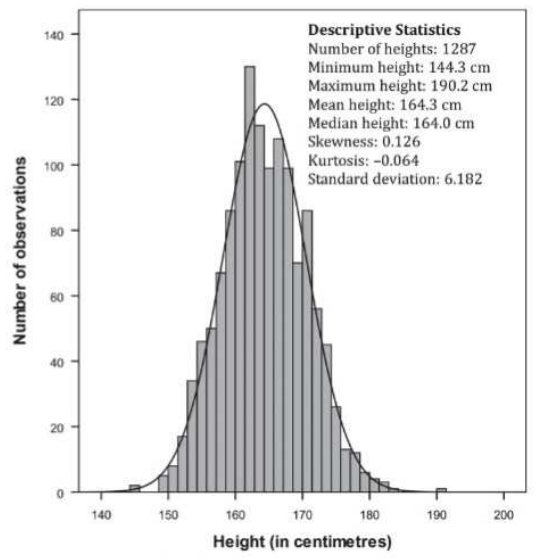

(b) All conscripts from Igualada

Figure 3. Distribution of heights of conscripts from Igualada(birth cohorts of 1845-1850, 1875-1880 and 1905-1910).

Notes and sources: Heights have been standardised. This distribution excludes a conscript being $103.4 \mathrm{~cm}$ tall. It is assumed that such short stature must be strongly influenced by disease, which might bias our final results. See Table 2 and text. 


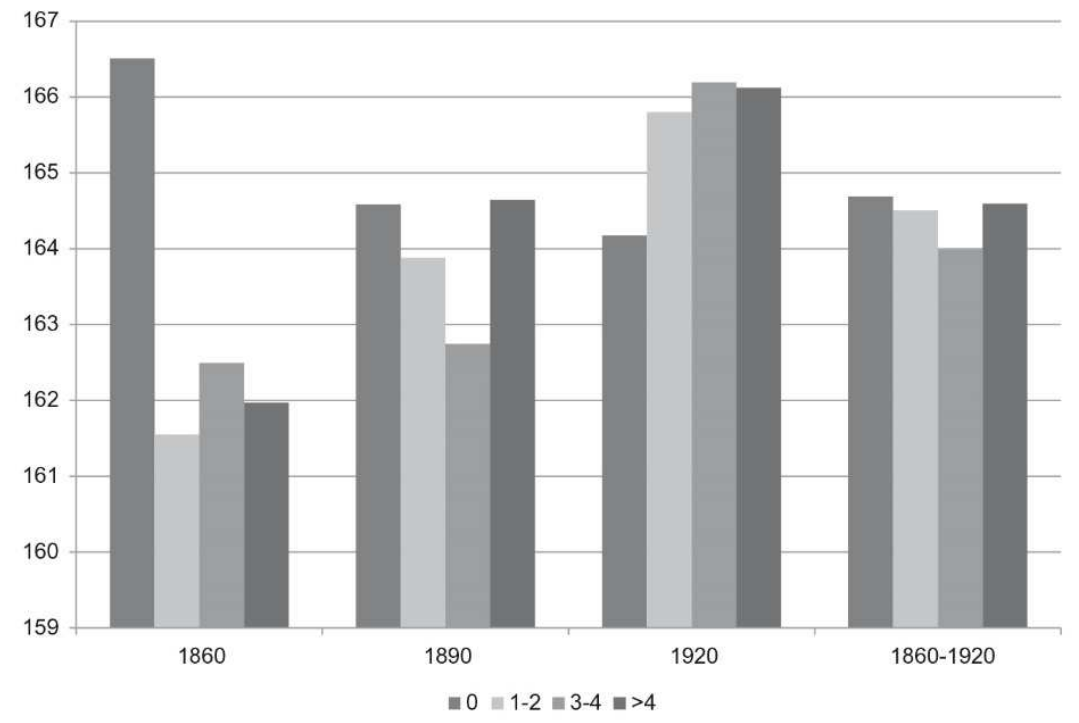

Figure 4. Height and sibship size in Igualada by population census year, $1860-1890$.

Notes and sources: Heights of draftees standardised at the age of 21 years (in $\mathrm{cm}) .1860$ (number of observations $=152) ; 1890(n=406) ; 1920(n=429)$. Standard Deviations: 1860 : 0 siblings: $7.698 ; 1-2$ siblings: 5.957 ; $3-4$ siblings: 5.879; >4 siblings: 7.535; total siblings: 6.291. 1890: 0: 5.713; 1-2: 6.305; 3-4: 5.618; >4: 6.867; total: 6.094. 1920: 0: 5.727; 1-2: 6.168; 3-4: 5.073. >4: 5.305; total: 5.816. 1860-1920: 0: 6.003; 1-2: 6.353; 3-4: 5.712; >4: 6.634; total: 6.144. See also Tables 1 and 2. In general, heights by sibship size and census year are not statistically different from the mean height for the focus census year. The only exception is 1860 , when draftees with no siblings were taller than the mean height of conscripts, the difference being statistically significant $(t=-$ $2.184, \mathrm{p}=0.030$ ). 


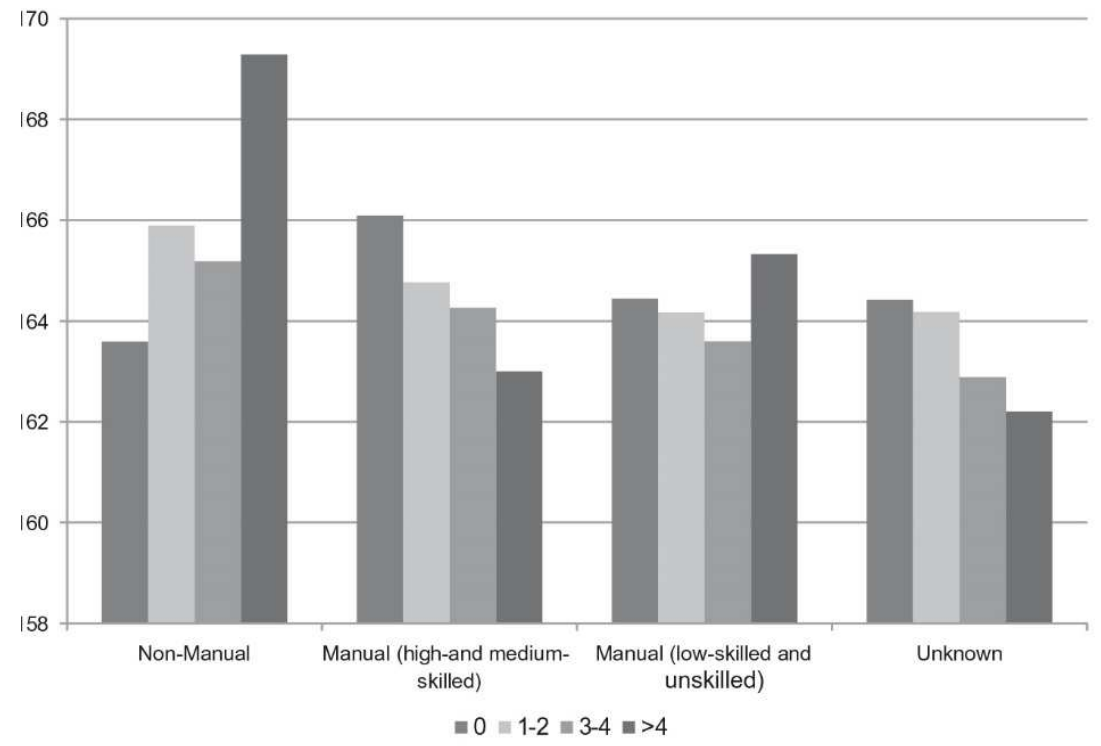

Figure 5. Height and sibship size in Igualada by occupation, 1860-1920.

Notes and sources: Heights of draftees standardised at the age of 21 years (in $\mathrm{cm}$ ). Non-Manual (number of observations = 114); Manual, high- and mediumskilled $(n=297)$; Manual, low-skilled and unskilled $(n=405)$; Unknown $(n=$ 171). Standard Deviations: Non-Manual: 0 siblings: 5.785; 1-2 siblings: 6.499; 3-4 siblings: 6.317 ; $>4$ siblings: 6.433 ; total siblings: 6.416 . Manual, high- and medium-skilled: $0: 6.093 ; 1-2: 6.581 ; 3-4: 5.872 ;>4: 6.280$, total: 6.269 . Manual, low- skilled and unskilled: 0: 5.593; 1-2: 6.040; 3-4: 5.434; >4: 6.270; total: 5.834. Unknown occupation: $0: 6.720 ; 1-2: 6.600 ; 3-4: 5.187 ;>4: 6.846$; total: 6.365. See also Tables 1 and 2. Heights by sibship size and occupation are not statistically different from the mean height of the focus occupation or economic sector. 


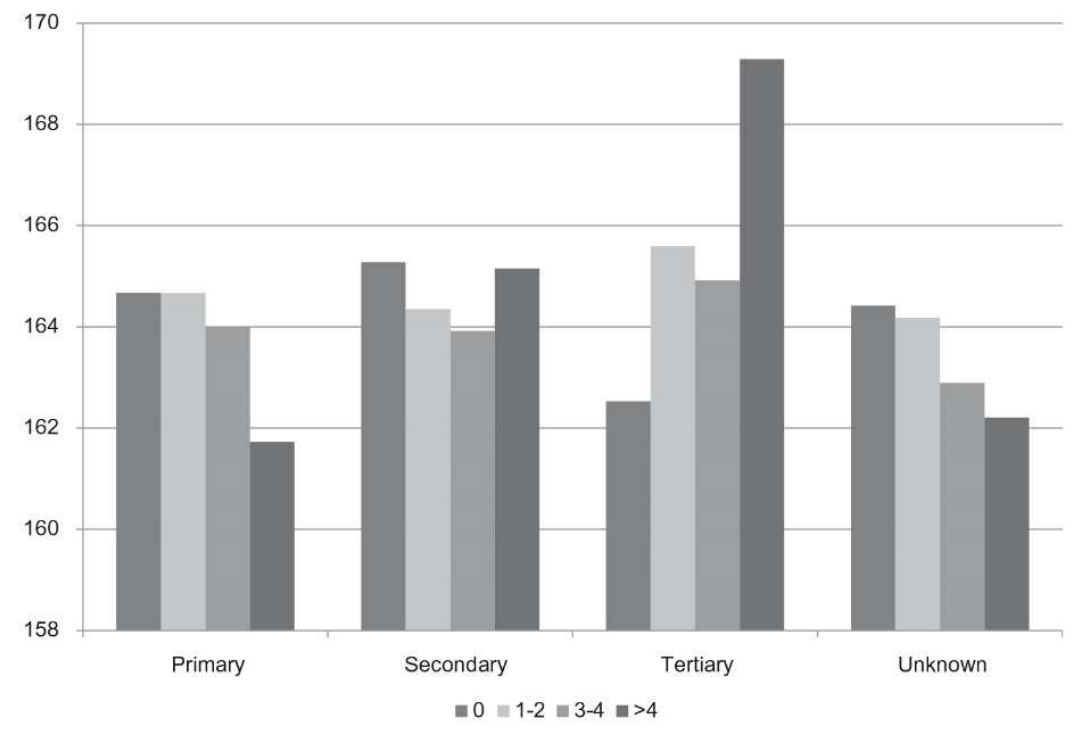

Figure 6. Height and sibship size in Igualada by economic sector, 1860 1890.

Notes and sources: Heights of draftees standardised at the age of 21 years (in $\mathrm{cm})$. Primary $(n=156)$; Secondary $(n=529)$; Tertiary $(n=131)$; Unknown $(n=$ 171). Standard Deviations: Primary: 0 siblings: $6.413 ; 1-2$ siblings: $6.630 ; 3-4$ : 5.696; >4 siblings: 7.601; total siblings: 6.349. Secondary: 0: 5.575; 1-2: 6.167; 3-4: 5.723; >4: 5.518; total: 5.939; 0: 6.286; 1-2: 6.487; 3-4: 6.029; >4: 6.433; total: 6.367. See also Tables 2 and 3, and Figure 5. In general, heights by sibship size and economic sector are not statistically different from the mean height of the focus occupation or economic sector. The only exception to this rule is the group of draftees with more than four siblings and whose father works in the tertiary sector, the difference being statistically significant at the $10 \%$ significance level $(t=-1.859, \mathrm{p}=0.065)$. 
Table 1. Number of conscripts and families in Igualada in the selected cohorts.

\begin{tabular}{|c|c|c|c|c|c|}
\hline \multirow[b]{2}{*}{$\begin{array}{l}\text { Year of } \\
\text { birth }\end{array}$} & \multirow[b]{2}{*}{$\begin{array}{l}\text { Year of } \\
\text { recruitment }\end{array}$} & \multicolumn{3}{|c|}{ No. of conscripts } & \multirow[b]{2}{*}{$\begin{array}{l}\text { No. of } \\
\text { families }\end{array}$} \\
\hline & & Total & $\begin{array}{l}\text { with } \\
\text { height } \\
\text { data }\end{array}$ & $\begin{array}{l}\text { with height data and } \\
\text { found in the population } \\
\text { censuses }\end{array}$ & \\
\hline $1845-1850$ & $1865-1870$ & 439 & 224 & $152[1860]$ & 148 [1860] \\
\hline $1875-1880$ & $1894-1899$ & 606 & 470 & $407[1890]$ & 368 [1890] \\
\hline $1905-1910$ & 1926-1931 & 663 & 594 & $429[1920]$ & 386 [1920] \\
\hline Total & & 1708 & 1288 & 988 & 902 \\
\hline
\end{tabular}

Notes and sources: No data for 1849. Data in brackets refer to the population census year. No. of families refers to those families containing conscripts for whom height data is available and who can be found in the population censuses. See text for the observed differences between the total number of conscripts and the total number of conscripts with height data. Actas de Clasificación $y$ declaración de soldados, 1865-1870, 1894-1899 and 1926-1931, and Padrón municipal de población, 1860; Ayuntamiento constitucional de la ciudad de Igualada. Padrón general de vecinos 1890. Igualada: Imprenta y Fábrica de Rayados de Mariano Abadal, Padrón general de Igualada, 1920. ACAN. 
Table 2. Descriptive statistics for the Igualada dataset.

\begin{tabular}{|c|c|c|c|c|}
\hline Groups & 1860 & 1890 & 1920 & Total \\
\hline \multicolumn{5}{|l|}{ Panel 1. Height (non-standardised) } \\
\hline Age & 20 & 19 & 21 & $19-21$ \\
\hline Obs. & 152 & 406 & 429 & 987 \\
\hline Mean & 161.7 & 162.3 & 165.8 & 163.7 \\
\hline Std. Dev. & 6.291 & 6.094 & 5.816 & 6.275 \\
\hline Min. & 148.0 & 143.0 & 148.6 & 143.0 \\
\hline Max. & 179.2 & 180.3 & 190.2 & 190.2 \\
\hline \multicolumn{5}{|l|}{ Panel 2. Height (standardised) } \\
\hline Age (standardised) & 21 & 21 & 21 & 21 \\
\hline Obs. & 152 & 406 & 429 & 987 \\
\hline Mean & 162.3 & 163.6 & 165.8 & 164.4 \\
\hline Std. Dev. & 6.291 & 6.094 & 5.816 & 6.144 \\
\hline Min. & 148.7 & 144.4 & 148.6 & 144.4 \\
\hline Max. & 179.9 & 181.7 & 190.2 & 190.2 \\
\hline \multicolumn{5}{|c|}{ Panel 3. Sibship size of the recruit (including the recruit himself) } \\
\hline 1 & $7.9 \%$ & $9.1 \%$ & $8.2 \%$ & $8.5 \%$ \\
\hline 2 & $21.7 \%$ & $18.7 \%$ & $31.9 \%$ & $24.9 \%$ \\
\hline 3 & $25.7 \%$ & $28.3 \%$ & $27.7 \%$ & $27.7 \%$ \\
\hline 4 & $24.3 \%$ & $21.2 \%$ & $17.7 \%$ & $20.2 \%$ \\
\hline 5 & $11.8 \%$ & $13.5 \%$ & $9.6 \%$ & $11.6 \%$ \\
\hline 6 & $5.3 \%$ & $5.7 \%$ & $2.1 \%$ & $4.1 \%$ \\
\hline$>6$ & $3.3 \%$ & $3.4 \%$ & $2.8 \%$ & $3.1 \%$ \\
\hline \multirow[t]{2}{*}{ Total } & $100.0 \%$ & $100.0 \%$ & $100.0 \%$ & $100.0 \%$ \\
\hline & $(n=152)$ & $(n=406)$ & $(n=429)$ & $(n=987)$ \\
\hline Mean & 3.40 & 3.43 & 3.08 & 3.27 \\
\hline Std. Dev. & 1.471 & 1.502 & 1.431 & 1.475 \\
\hline Min. & 1 & 1 & 1 & 1 \\
\hline Max. & 8 & 8 & 10 & 10 \\
\hline \multicolumn{5}{|c|}{ Panel 4. Birth order of the recruit within his family } \\
\hline $1 \mathrm{st}$ & $36.2 \%$ & $33.3 \%$ & $38.9 \%$ & $36.2 \%$ \\
\hline $2 n d$ & $31.6 \%$ & $31.8 \%$ & $30.3 \%$ & $31.1 \%$ \\
\hline $3 \mathrm{rd}$ & $25.0 \%$ & $21.4 \%$ & $17.7 \%$ & $20.4 \%$ \\
\hline 4th & $5.9 \%$ & $10.6 \%$ & $9.1 \%$ & $9.2 \%$ \\
\hline 5 th & $0.7 \%$ & $2.2 \%$ & $3.0 \%$ & $2.3 \%$ \\
\hline 6th & $0.7 \%$ & $0.7 \%$ & $0.9 \%$ & $0.8 \%$ \\
\hline \multirow[t]{2}{*}{ Total } & $100.0 \%$ & $100.0 \%$ & $100.0 \%$ & $100.0 \%$ \\
\hline & $(n=152)$ & $(n=406)$ & $(n=429)$ & $(n=987)$ \\
\hline Mean & 2.05 & 2.19 & 2.10 & 2.13 \\
\hline Std. Dev. & 1.009 & 1.120 & 1.160 & 1.122 \\
\hline Min. & 1 & 1 & 1 & 1 \\
\hline Max. & 6 & 6 & 6 & 6 \\
\hline \multicolumn{5}{|c|}{ Panel 5. Occupation and socioeconomic group of the recruit's father } \\
\hline Non-Manual & $7.2 \%$ & $10.8 \%$ & $13.8 \%$ & $11.6 \%$ \\
\hline Manual, high- and medium-skilled & $28.3 \%$ & $37.4 \%$ & $23.8 \%$ & $30.1 \%$ \\
\hline Manual, low-skilled and unskilled & $46.1 \%$ & $34.0 \%$ & $45.9 \%$ & $41.0 \%$ \\
\hline Unknown & $18.4 \%$ & $17.7 \%$ & $16.6 \%$ & $17.3 \%$ \\
\hline \multirow[t]{2}{*}{ Total } & $100.0 \%$ & $100.0 \%$ & $100.0 \%$ & $100.0 \%$ \\
\hline & $(n=152)$ & $(n=406)$ & $(n=429)$ & $(n=987)$ \\
\hline Primary & $18.4 \%$ & $20.7 \%$ & $10.3 \%$ & $15.8 \%$ \\
\hline Secondary & $55.3 \%$ & $48.8 \%$ & $57.6 \%$ & $53.6 \%$ \\
\hline Tertiary & $7.9 \%$ & $12.8 \%$ & $15.6 \%$ & $13.3 \%$ \\
\hline Unknown & $18.4 \%$ & $17.7 \%$ & $16.6 \%$ & $17.3 \%$ \\
\hline \multirow[t]{2}{*}{ Total } & $100.0 \%$ & $100.0 \%$ & $100.0 \%$ & $100.0 \%$ \\
\hline & $(n=152)$ & $(n=406)$ & $(n=429)$ & $(n=987)$ \\
\hline
\end{tabular}

Notes and sources: Occupations and socioeconomic groups in our dataset are grouped using the HISCO/HISCLASS classification and according to the following code numbers: Non-Manual: 1, 2, 3, 4, 5; Manual, high- and mediumskilled: 6, 7, 8; Manual, low-skilled and unskilled: 9, 10, 11, 12; Primary sector: 6; Secondary sector: 7, 8, 9; Tertiary sector: 0, 1, 2, 3, 4, 5. Van Leeuwen, Maas, and Miles (2002, 2004), and Van Leeuwen and Maas (2011); and Pujadas-Mora et al. (2014). See also Table 1. 
Table 3. The impact of sibship size on height in Igualada, 1860-1920 (I): overall results (dependent variable: NonStandardised Height, $\mathrm{cm}$ ).

\begin{tabular}{|c|c|c|c|c|c|c|}
\hline Variables & (1) & (2) & (3) & (4) & (5) & (6) \\
\hline Sibship Size $\mathrm{e}_{\mathrm{jt}}$ & $\begin{array}{c}-0.014 \\
(0.132)\end{array}$ & $\begin{array}{c}-0.025 \\
(0.133)\end{array}$ & $\begin{array}{c}-0.047 \\
(0.133)\end{array}$ & $\begin{array}{l}-0.058 \\
(0.133)\end{array}$ & $\begin{array}{c}0.130 \\
(0.202)\end{array}$ & $\begin{array}{c}0.104 \\
(0.201)\end{array}$ \\
\hline Census 1920 - Age of Inspection 21 & Ref. & Ref. & Ref. & Ref. & Ref. & \\
\hline Census 1890 - Age of Inspection 19 & $\begin{array}{l}-3.516 * * * \\
(0.412)\end{array}$ & $\begin{array}{l}-3.433^{* * *} \\
(0.419)\end{array}$ & $\begin{array}{l}-3.581^{* * *} \\
(0.413)\end{array}$ & $\begin{array}{l}-3.509^{* * *} \\
(0.419)\end{array}$ & $\begin{array}{l}-3.555^{* * *} \\
(0.412)\end{array}$ & $\begin{array}{l}-3.485^{* * *} \\
(0.418)\end{array}$ \\
\hline Census 1860 - Age of Inspection 20 & $\begin{array}{l}-4.117 * * * \\
(0.582)\end{array}$ & $\begin{array}{l}-3.767^{* * *} \\
(0.621)\end{array}$ & $\begin{array}{l}-4.089^{* * * *} \\
(0.592)\end{array}$ & $\begin{array}{l}-3.762^{* * *} \\
(0.627)\end{array}$ & $\begin{array}{l}-4.151^{* * * * *} \\
(0.591)\end{array}$ & $\begin{array}{l}-3.833^{* * *} \\
(0.627)\end{array}$ \\
\hline Birth Order Index $x_{\mathrm{jt}}$ & & $\begin{array}{r}-0.711 \\
(0.524)\end{array}$ & $\begin{array}{c}-0.717 \\
(0.522)\end{array}$ & $\begin{array}{c}-0.703 \\
(0.523)\end{array}$ & $\begin{array}{c}-0.698 \\
(0.524)\end{array}$ & $\begin{array}{c}-0.683 \\
(0.525)\end{array}$ \\
\hline Illiterate Father $r_{j t}$ & & & & Ref. & & \\
\hline Literate Father ${ }_{j t}$ & & $\begin{array}{l}0.982^{* *} \\
(0.467)\end{array}$ & & $\begin{array}{r}0.824^{*} \\
(0.484)\end{array}$ & & $\begin{array}{c}0.789 \\
(0.482)\end{array}$ \\
\hline Unknown Literacy Status of the Father ${ }_{j t}$ & & $\begin{array}{c}0.257 \\
(0.638)\end{array}$ & & $\begin{array}{r}0.741 \\
(1.556)\end{array}$ & & $\begin{array}{r}0.799 \\
(1.526)\end{array}$ \\
\hline $\begin{array}{l}\text { Low-skilled and Unskilled Manual } \\
\text { Occupation (LSUMO) }\end{array}$ & & & Ref. & Ref. & Ref. & Ref. \\
\hline $\begin{array}{l}\text { High-and Medium-Skilled Occupation } \\
\text { (HMSMO) })_{\mathrm{jt}}\end{array}$ & & & 0.706 & 0.724 & $2.372^{* *}$ & $2.293^{*}$ \\
\hline & & & $(0.463)$ & $(0.464)$ & $(1.208)$ & $(1.206)$ \\
\hline Non-Manual Occupation $(\mathrm{NMO})_{\mathrm{j}}$ & & & $\begin{array}{l}1.525^{* *} \\
(0.652)\end{array}$ & $\begin{array}{l}1.295^{*} \\
(0.665)\end{array}$ & $\begin{array}{c}0.001 \\
(1.606)\end{array}$ & $\begin{array}{l}-0.303 \\
(1.601)\end{array}$ \\
\hline Unknown Occupation (UNKO) $)_{k t}$ & & & $\begin{array}{c}-0.016 \\
(0.556)\end{array}$ & $\begin{array}{c}-0.197 \\
(1.481)\end{array}$ & $\begin{array}{c}1.577 \\
(1.344)\end{array}$ & $\begin{array}{c}1.259 \\
(1.789)\end{array}$ \\
\hline $\begin{array}{l}\left(\text { Sibship Size }_{\mathrm{jk}}\right) \times\left(\text { (LSUMO }_{\mathrm{H}}\right) \\
\left(\text { Sibship Size }_{\mathrm{jt}}\right) \times\left(\mathrm{HMSMO}_{\mathrm{jL}}\right)\end{array}$ & & & & & $\begin{array}{l}\text { Ref. } \\
-0.492 \\
(0.317)\end{array}$ & $\begin{array}{l}\text { Ref. } \\
-0.463 \\
(0.318)\end{array}$ \\
\hline$\left(\right.$ Sibship Size $\left._{\mathrm{j}}\right) \times\left(\mathrm{NMO}_{\mathrm{jt}}\right)$ & & & & & $\begin{array}{c}0.414 \\
(0.431)\end{array}$ & $\begin{array}{r}0.440 \\
(0.427)\end{array}$ \\
\hline$\left(\right.$ Sibship Size $\left._{\mathrm{jt}}\right) \times\left(\mathrm{UNKO}_{\mathrm{jt}}\right)$ & & & & & $\begin{array}{c}-0.535 \\
(0.388)\end{array}$ & $\begin{array}{c}-0.514 \\
(0.391)\end{array}$ \\
\hline Constant & $165.8^{* * *}$ & $165.9^{* * *}$ & $166.3^{* * *}$ & $165.7^{* * *}$ & $165.7^{* * *}$ & $165.2^{* * *}$ \\
\hline & $(0.518)$ & $(0.822)$ & $(0.734)$ & $(0.840)$ & $(0.864)$ & $(0.948)$ \\
\hline$R^{2}$ & 0.086 & 0.092 & 0.095 & 0.097 & 0.100 & 0.103 \\
\hline Observations & 987 & 987 & 987 & 987 & 987 & 987 \\
\hline
\end{tabular}

Notes: Robust standard errors are given in brackets.

$* * * p<0.01 ; * * p<0.05 ; * p<0.10$. 
Table 4. The impact of sibship size on height in the group of highand medium-skilled manual workersin Igualada over time, 18601920 (dependent variable: Non-Standardised Height, $\mathrm{cm}$ ).

\begin{tabular}{lcccc}
\hline Variables & 1860 & 1890 & 1920 & $1860-1920$ (pooled) \\
\hline Sibship Size ${ }_{\mathrm{jt}}$ & -0.281 & $-0.645^{*}$ & 0.002 & -0.369 \\
& $(0.804)$ & $(0.344)$ & $(0.382)$ & $(0.245)$ \\
Census 1860 - Age Insp. 20 & - & - & - & $\left(1.413^{* * *}\right.$ \\
& & & $-2.992^{* * *}$ \\
Census 1890-Age Insp. 19 & - & - & $(0.804)$ \\
& - & - & - & Ref. $^{*}$ \\
Census 1920-Age Insp. 21 & & & -0.022 \\
& 0.776 & 1.211 & -1.834 & $(0.989)$ \\
Birth Order Index & $(2.255)$ & $(1.470)$ & $(1.694)$ & 0.737 \\
& -1.684 & 1.508 & 0.726 & $(0.744)$ \\
Literate Father & $(2.002)$ & $(0.995)$ & $(1.343)$ & $166.7^{* * *}$ \\
& $162.2^{* * *}$ & $163.1^{* * *}$ & $167.3^{* * *}$ & $(1.611)$ \\
Constant & $(4.147)$ & $(2.009)$ & $(2.527)$ & 0.088 \\
$R^{2}$ & 0.026 & 0.039 & 0.015 & 297 \\
Observations & 43 & 152 & 102 & \\
\hline
\end{tabular}

Notes: Robust standard errors are given in brackets. See also text and notes. $* * * p<0.01$; ** $p<0.05 ; * p<0.10$. 


\section{Appendix}

Table A1. .The impact of sibship size on height in Igualada, 1860-1920 (II): overall results (dependent variable: Non-Standardised Height, $\mathrm{cm})$.

\begin{tabular}{|c|c|c|c|c|c|c|}
\hline Variables & (1) & (2) & (3) & (4) & (5) & (6) \\
\hline$\overline{\text { Sibship Size }}_{k}$ & $\begin{array}{l}-0.014 \\
(0.132)\end{array}$ & $\begin{array}{l}-0.025 \\
(0.133)\end{array}$ & $\begin{array}{l}-0.028 \\
(0.132)\end{array}$ & $\begin{array}{l}-0.445 \\
(0.132)\end{array}$ & $\begin{array}{l}-0.485 \\
(0.368)\end{array}$ & $\begin{array}{l}-0.492 \\
(0.372)\end{array}$ \\
\hline Census 1920 - Age of Inspection 21 & & & & & & \\
\hline Census 1890 - Age of Inspection 19 & $-3.516^{* * * *}$ & $-3.433^{* * * *}$ & $-3.534^{* * *}$ & $-3.472^{* * * *}$ & $-3.503^{* * *}$ & $-3.441 * * *$ \\
\hline Census 1860 - Age of Inspection 20 & $\begin{array}{l}(0.412) \\
-4.117^{* * * *}\end{array}$ & $\begin{array}{l}(0.419) \\
-3.767 * * *\end{array}$ & $\begin{array}{l}(0.413) \\
-4.110^{* * *}\end{array}$ & $\begin{array}{l}(0.418) \\
-3.742^{* * * *}\end{array}$ & $\begin{array}{l}(0.412) \\
-4.136^{* * * *}\end{array}$ & $\begin{array}{l}(0.417) \\
-3.770^{* * *}\end{array}$ \\
\hline & $(0.582)$ & $(0.621)$ & $(0.591)$ & $(0.625)$ & $(0.588)$ & $(0.621)$ \\
\hline Birth Order Index ${ }_{\mathrm{jt}}$ & & $\begin{array}{l}-0.711 \\
(0.524)\end{array}$ & $\begin{array}{l}-0.755 \\
(0.524)\end{array}$ & $\begin{array}{l}-0.753 \\
(0.524)\end{array}$ & $\begin{array}{l}-0.689 \\
(0.526)\end{array}$ & $\begin{array}{l}-0.689 \\
(0.526)\end{array}$ \\
\hline $\begin{array}{l}\text { Illiterate Father }{ }_{j t} \\
\text { Literate Father } r_{j}\end{array}$ & & $\begin{array}{l}\text { Ref. } \\
0.982^{* *} \\
(0.467)\end{array}$ & & $\begin{array}{l}\text { Ref. } \\
0.985^{*} \\
(0.508)\end{array}$ & & $\begin{array}{l}\text { Ref. } \\
0.971^{*} \\
(0.506)\end{array}$ \\
\hline Unknown Literacy Status of the Father $r_{\mathrm{j}}$ & & $\begin{array}{l}0.257 \\
(0.638)\end{array}$ & & $\begin{array}{l}0.827 \\
(1.561)\end{array}$ & & $\begin{array}{l}0.882 \\
(1.526)\end{array}$ \\
\hline $\begin{array}{l}\text { Primary Sector Occupation }\left(\mathrm{PSO}_{\mathrm{I}}\right. \\
\text { Secondary Sector Occupation }\left(\mathrm{PS}^{\circ}\right)_{\mid t}\end{array}$ & & & $\begin{array}{l}\text { Ref. } \\
-0.256 \\
(0.566)\end{array}$ & $\begin{array}{l}\text { Ref. } \\
-0.539 \\
(0.594)\end{array}$ & $\begin{array}{l}\text { Ref. } \\
-2.098 \\
(1.556)\end{array}$ & $\begin{array}{l}\text { Ref. } \\
-2.307 \\
(1.565)\end{array}$ \\
\hline Tertiary Sector Occupation (PSO) $)_{\mathrm{jt}}$ & & & $\begin{array}{l}0.658 \\
0.741)\end{array}$ & $\begin{array}{l}0.168 \\
(0.799)\end{array}$ & $\begin{array}{l}-3.274 \\
(2.005)\end{array}$ & $\begin{array}{l}-3.760^{*} \\
(2.015)\end{array}$ \\
\hline Unknown Sector Occupation (UNKSO) & & & $\begin{array}{l}-0.533 \\
(0.698)\end{array}$ & $\begin{array}{l}-0.928 \\
(1.535)\end{array}$ & $\begin{array}{l}-1.076 \\
(1.831)\end{array}$ & $\begin{array}{l}-1.531 \\
(2.198)\end{array}$ \\
\hline 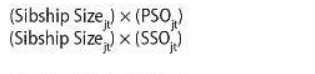 & & & & & $\begin{array}{l}\text { Ref. } \\
0.523 \\
(0.404)\end{array}$ & $\begin{array}{l}\text { Ref. } \\
0.503 \\
(0.408)\end{array}$ \\
\hline$\left(\right.$ Sibship Size $\left._{j}\right) \times\left(\mathrm{TSO}_{\mu}\right)$ & & & & & $\begin{array}{l}1.116^{* *} \\
(0.523)\end{array}$ & $\begin{array}{l}1.1177^{* *} \\
(0.524)\end{array}$ \\
\hline$\left.(\text { Sibship Size })_{\mathrm{jl}}\right) \times\left(\mathrm{UNKSO}_{\mathrm{jl}}\right)$ & & & & & $\begin{array}{l}0.078 \\
(0.494)\end{array}$ & $\begin{array}{l}0.082 \\
(0.499)\end{array}$ \\
\hline Constant & $165.8^{* * *}$ & $165.9 * * *$ & $166.8^{* * *}$ & $166.3^{* * *}$ & $168.3^{* * * *}$ & $167.9 * * *$ \\
\hline & $(0.518)$ & $(0.822)$ & $(0.908)$ & $(0.933)$ & (1.525) & $(1.563)$ \\
\hline$R^{2}$ & 0.086 & 0.092 & 0.091 & 0.094 & 0.097 & 0.100 \\
\hline Observations & 987 & 987 & 987 & 987 & 987 & 987 \\
\hline
\end{tabular}

Notes: Robust standard errors are given in brackets. $* * * p<0.01, * * p<0.05, * p<0.10$. 
Table A2. The impact of sibship size on height in Igualada by census years, 1860-1920: pooled regression(dependent variable: Non-Standardised Height, $\mathrm{cm}$ ).

\begin{tabular}{|c|c|}
\hline Variables & Results \\
\hline Sibship Size $_{j \mathrm{t}}$ & $\begin{array}{l}0.117 \\
(0.191)\end{array}$ \\
\hline Census 1860 - Age of Inspection 20 & $\begin{array}{l}-1.394 \\
(2.387)\end{array}$ \\
\hline Census 1890 - Age of Inspection 19 & $\begin{array}{c}-3.477^{* *} \\
(1.760)\end{array}$ \\
\hline $\begin{array}{l}\text { Census } 1920 \text { - Age of Inspection } 21 \\
\text { Birth Order Index } \\
\text { jt }\end{array}$ & $\begin{array}{l}\text { Ref. } \\
-1.028 \\
(0.775)\end{array}$ \\
\hline $\begin{array}{l}\text { Illiterate Father } \\
\text { Literate Father } \\
\text { jt }\end{array}$ & $\begin{array}{l}\text { Ref. } \\
1.117 \\
(0.816)\end{array}$ \\
\hline Unknown Literacy Status of the Father $_{j \mathrm{t}}$ & $\begin{array}{c}1.578 \\
(2.191)\end{array}$ \\
\hline $\begin{array}{l}\text { Low-skilled and Unskilled Manual Occupation (LSUMO) } \\
\text { High- and Medium-Skilled Occupation (HMSMO) } \\
\text { jt }\end{array}$ & $\begin{array}{l}\text { Ref. } \\
0.418 \\
(0.724)\end{array}$ \\
\hline Non-Manual Occupation (NMO) $)_{\mathrm{jt}}$ & $\begin{array}{l}1.206 \\
(0.886)\end{array}$ \\
\hline Unknown Occupation (UNKO) ${ }_{\mathrm{jt}}$ & $\begin{array}{l}-0.895 \\
(2.082)\end{array}$ \\
\hline \multicolumn{2}{|l|}{ Interactions (Ref. Census 1920): } \\
\hline$\left(\right.$ Sibship Size $\left._{\mathrm{jt}}\right) \times($ Dummy Census 1860) & $\begin{array}{c}-0.232 \\
(0.429)\end{array}$ \\
\hline$\left(\right.$ Sibship Size $\left.\mathrm{jt}_{\mathrm{jt}}\right) \times($ Dummy Census 1890) & $\begin{array}{l}-0.285 \\
(0.284)\end{array}$ \\
\hline$\left(\right.$ Birth Order Index $\left.{ }_{\mathrm{jt}}\right) \times($ Dummy Census 1860) & $\begin{array}{c}-1.214 \\
(1.581)\end{array}$ \\
\hline (Birth Order Index $\left.{ }_{\mathrm{jt}}\right) \times($ Dummy Census 1890) & $\begin{array}{l}0.910 \\
(1.163)\end{array}$ \\
\hline$\left(\right.$ Literate Father $\left.{ }_{\mathrm{jt}}\right) \times($ Dummy Census 1860$)$ & $\begin{array}{c}0.141 \\
(1.418)\end{array}$ \\
\hline$\left(\right.$ Literate Father $\left._{\mathrm{jt}}\right) \times($ Dummy Census 1890$)$ & $\begin{array}{l}-0.653 \\
(1.082)\end{array}$ \\
\hline (Unknown Literacy Status of the Father $\left._{\mathrm{jt}}\right) \times($ Dummy Census 1860$)$ & $\begin{array}{l}1.357 \\
(3.106)\end{array}$ \\
\hline (Unknown Literacy Status of the Father $\left.{ }_{\mathrm{jt}}\right) \times($ Dummy Census 1890) & $\begin{array}{c}-4.252 \\
(4.509)\end{array}$ \\
\hline$\left(\mathrm{HMSMO}_{\mathrm{jt}}\right) \times($ Dummy Census 1860$)$ & $\begin{array}{c}-1.146 \\
(1.386)\end{array}$ \\
\hline$\left(\mathrm{HMSMO}_{\mathrm{jt}}\right) \times($ Dummy Census 1890$)$ & $\begin{array}{c}0.978 \\
(1.024)\end{array}$ \\
\hline$\left(\mathrm{NMO}_{\mathrm{jt}}\right) \times($ Dummy Census 1860$)$ & $\begin{array}{l}-4.215 \\
(2.719)\end{array}$ \\
\hline$\left(\mathrm{NMO}_{\mathrm{jt}}\right) \times($ Dummy Census 1890$)$ & $\begin{array}{c}1.161 \\
(1.363)\end{array}$ \\
\hline$\left(\mathrm{UNKO}_{\mathrm{jt}}\right) \times($ Dummy Census 1860) & $\begin{array}{l}0.118 \\
(2.792)\end{array}$ \\
\hline$\left(\right.$ UNKO $\left._{\mathrm{jt}}\right) \times($ Dummy Census 1890$)$ & $\begin{array}{c}3.711 \\
(4.382)\end{array}$ \\
\hline Constant & $\begin{array}{r}165.4^{* * *} \\
(1.170)\end{array}$ \\
\hline $\begin{array}{l}\text { R-squared } \\
\text { Observations }\end{array}$ & $\begin{array}{l}0.109 \\
987\end{array}$ \\
\hline
\end{tabular}

Notes: $* * * p<0.01, * * p<0.05, * p<0.10$. Robust standard errors are given in brackets. 
Table A3. The impact of sibship size on height by socioeconomic groups (excluding high- and medium-skilled manual workers) in Igualada over time, 1860-1920 (dependent variable: NonStandardisedHeight, $\mathrm{cm}$ ).

\begin{tabular}{|c|c|c|c|c|}
\hline \multicolumn{5}{|c|}{ Panel 1. Low-Skilled and Unskilled Manual Workers (LSUMO) } \\
\hline Variables & 1860 & 1890 & \multicolumn{2}{|c|}{1920} \\
\hline Sibship Size $_{j t}$ & $\begin{array}{c}0.062 \\
(0.540)\end{array}$ & $\begin{array}{c}0.349 \\
(0.376)\end{array}$ & \multicolumn{2}{|c|}{$\begin{array}{c}-0.085 \\
(0.248)\end{array}$} \\
\hline Birth Order Index ${ }_{j t}$ & $\begin{array}{c}-3.229^{*} \\
(1.653)\end{array}$ & $\begin{array}{c}0.115 \\
(1.177)\end{array}$ & \multicolumn{2}{|c|}{$\begin{array}{c}-0.294 \\
(1.093)\end{array}$} \\
\hline Literate Father $_{\mathrm{jt}}$ & $\begin{array}{l}3.811^{* * *} \\
(1.387)\end{array}$ & $\begin{array}{c}-1.049 \\
(1.015)\end{array}$ & & \\
\hline Constant & $\begin{array}{r}163.6^{* * * *} \\
(2.554)\end{array}$ & $\begin{array}{r}161.0^{* * * *} \\
(1.877)\end{array}$ & \multicolumn{2}{|c|}{$\begin{array}{r}165.1^{* * *} \\
(1.446)\end{array}$} \\
\hline R-squared & 0.116 & 0.014 & \multicolumn{2}{|c|}{0.011} \\
\hline Observations & 70 & 138 & \multicolumn{2}{|c|}{197} \\
\hline \multicolumn{5}{|c|}{ Panel 2. Non-Manual Workers and Workers with Unknown Occupation } \\
\hline & \multicolumn{2}{|c|}{ Non-Manual Workers } & \multicolumn{2}{|c|}{ Unknown Occupation } \\
\hline Variables & 1890 & 1920 & 1890 & 1920 \\
\hline Sibship Size $_{j t}$ & $\begin{array}{c}0.386 \\
(0.487)\end{array}$ & $\begin{array}{c}0.611 \\
(0.574)\end{array}$ & $\begin{array}{c}-0.380 \\
(0.531)\end{array}$ & $\begin{array}{c}0.561 \\
(0.563)\end{array}$ \\
\hline Birth Order Index $x_{j t}$ & $\begin{array}{c}-1.654 \\
(2.630)\end{array}$ & $\begin{array}{c}-1.044 \\
(2.185)\end{array}$ & $\begin{array}{c}-1.839 \\
(2.811)\end{array}$ & $\begin{array}{r}-2.363 \\
(2.049)\end{array}$ \\
\hline Literate Father $_{j \mathrm{t}}$ & - & - & $\begin{array}{c}4.151 \\
(4.252)\end{array}$ & $\begin{array}{r}2.180 \\
(2.859)\end{array}$ \\
\hline Constant & $\begin{array}{r}164.4^{* * *} \\
(3.358)\end{array}$ & $\begin{array}{r}165.9^{* * * *} \\
(3.122)\end{array}$ & $\begin{array}{r}164.5^{* * * *} \\
(3.037)\end{array}$ & $\begin{array}{r}165.9^{* * * *} \\
(2.416)\end{array}$ \\
\hline $\begin{array}{l}\text { R-squared } \\
\text { Observations }\end{array}$ & $\begin{array}{l}0.020 \\
44\end{array}$ & $\begin{array}{l}0.027 \\
59\end{array}$ & $\begin{array}{l}0.035 \\
72\end{array}$ & $\begin{array}{l}0.035 \\
71\end{array}$ \\
\hline \multicolumn{5}{|c|}{ Panel 3: Pooled Regressions: 1860-1920 } \\
\hline Variables & LSUMO & $\begin{array}{c}\text { Non-Manual } \\
\text { Workers }\end{array}$ & Unkr & upation \\
\hline Sibship Size $_{j t}$ & $\begin{array}{c}0.108 \\
(0.203)\end{array}$ & $\begin{array}{r}0.606 \\
(0.353)\end{array}$ & & \\
\hline Census 1860 - Age Insp. 20 & $\begin{array}{c}-3.341^{* * *} \\
(0.896)\end{array}$ & $\begin{array}{l}-9.617^{* * * *} \\
(2.728)\end{array}$ & & \\
\hline Census 1890 - Age Insp. 19 & $\begin{array}{l}-4.056^{* * *} \\
(0.621)\end{array}$ & $\begin{array}{l}-2.770^{* *} \\
(1.178)\end{array}$ & & $2^{* * *}$ \\
\hline Census 1920 - Age Insp. 21 & Ref. & Ref. & & \\
\hline Birth Order Index ${ }_{j t}$ & $\begin{array}{r}-0.723 \\
(0.744)\end{array}$ & $\begin{array}{r}-1.976 \\
(1.700)\end{array}$ & & \\
\hline Literate Father $_{\mathrm{jt}}$ & $\begin{array}{c}0.929 \\
(0.659)\end{array}$ & $\begin{array}{l}-5.709 \\
(3.851)\end{array}$ & & \\
\hline Constant & $\begin{array}{r}165.2^{* * *} \\
(1.112)\end{array}$ & $\begin{array}{r}172.4^{* * *} \\
(4.865)\end{array}$ & & \\
\hline R-squared & 0.115 & 0.177 & & \\
\hline Observations & 405 & 114 & & \\
\hline
\end{tabular}

Notes: $* * * p<0.01, * * p<0.05, * p<0.10$. Robust standard errors are given in brackets. See also text and notes.** 